\title{
Synthesis of fluorescent alanines by a rhodium catalysed conjugate addition of arylboronic acids to dehydroalanine derivatives
}

\author{
Paula M.T. Ferreira, ${ }^{[\mathrm{a}]}{ }^{*}$ Luís S. Monteiro, ${ }^{[\mathrm{a}]}$ Goreti Pereira, ${ }^{[\mathrm{a}]}$ Elisabete M.S. Castanheira, ${ }^{[\mathrm{b}]}$ and \\ Christopher G. Frost ${ }^{[\mathrm{c}] *}$
}

Keywords: dehydroalanines / rhodium-catalysis / arylboronic acids / conjugate addition / fluorescent marker

\begin{abstract}
Several $\beta$-arylalanine derivatives containing fluorescent groups were prepared in good yields using a rhodium catalysed conjugate addition of arylboronic acids to $N, N$-diprotected and $N$-monoprotected dehydroalanines. The best conditions for these reactions require the use of an excess of aryl boronic acid (4 equiv.), $\left[\mathrm{Rh}(\mathrm{COD})_{2}\right] \mathrm{BF}_{4}$ as catalyst and $\mathrm{CsF}$ as base in dioxane: $\mathrm{H}_{2} \mathrm{O}(10: 1)$ at $110{ }^{\circ} \mathrm{C}$. These conditions were also applied to several dipeptides with dehydroalanine residues.
\end{abstract}

\begin{abstract}
The photophysical properties of some of the $\beta$-arylalanines were studied in three solvents of different polarity. Due to the absence of the $\alpha, \beta$-double bond, the absorption and fluorescence emission of the new compounds are dominated by the photophysical properties of the polycyclic aromatic fluorophores (naphthalene, phenanthrene and pyrene). Considering the relatively high fluorescence quantum yield of these compounds, some of them may be useful as fluorescent markers for peptides and proteins.
\end{abstract}

[a] Centre of Chemistry, University of Minho, Campus de Gualtar, 4710-057 Braga, Portugal Fax: +351253604382

E-mail: pmf@quimica.uminho.pt

[b] Centre of Physics, University of Minho, Campus de Gualtar, 4710057 Braga, Portugal

[c] Department of Chemistry, University of Bath, UK, BA2 /AY Fax: +441225386231 E-mail: c.g.frost@bath.ac.uk

Supporting information for this article is available on the WWW under http://dx.doi.org/10.1002/ejoc.xxxxxxxxx.

\section{Introduction}

Transition-metal catalysed conjugate addition of organometallics to activated alkenes constitutes an important methodology for the construction of new C-C bonds. In particular the rhodium catalysed conjugate addition of organoboron compounds to $\alpha, \beta$-unsaturated carbonyl compounds has been an important tool in organic synthesis. ${ }^{[1]}$ This type of reaction was applied to the synthesis of new non-proteinogenic amino acids using $\alpha, \beta$-dehydroamino acid derivatives as substrates to afford different enantioselectivities that depended on the ligand. ${ }^{[2]}$ In recent years we have been interested in the synthesis of $\alpha, \beta$-dehydroamino acid derivatives and their application as substrates in several types of reactions to obtain new amino acids. ${ }^{[3]}$ Thus, an efficient synthetic procedure was developed that allowed the preparation of $N, N$-diacyldehydroamino acid derivatives from the corresponding $\beta$-hydroxyamino acids. Owing to the high reaction yields and to the simple work-up procedures we were able to prepare these compounds in large amounts and to use them successfully as substrates in Michael addition reactions. Herein, we describe the synthesis of fluorescent alanines from serine derivatives by a sequential dehydration and a rhodium catalysed conjugate addition of arylboronic acids.

\section{Results and Discussion}

Several fluorescent alanine derivatives were prepared using a rhodium catalysed conjugate addition of arylboronic acids to dehydroalanines. This reaction was initially screened using several reaction conditions and several types of substrates. Thus, $\mathrm{N}, \mathrm{N}$ diprotected and $N$-monoprotected dehydroalanines were synthesized from the corresponding serine derivatives using a methodology previously developed in our research group. ${ }^{[3 \mathrm{e}]}$ These compounds were then reacted with (naphthalen-1-yl)boronic acid under different conditions (Scheme 1, Table 1).

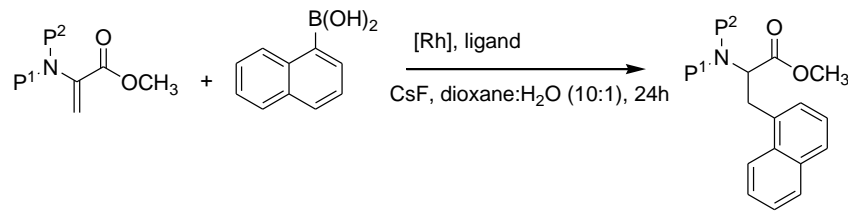

Scheme 1. Synthesis of $\beta$-naphthylalanine derivatives.

Table 1. Results obtained in the synthesis of $\beta$-naphthylalanine derivatives using different reaction conditions.

\begin{tabular}{lllllll}
\hline Entry & $\mathrm{P}^{1}$ & $\mathrm{P}^{2}$ & Catalyst & Ligand & Comp. & Yield/\% \\
\hline 1 & Boc & Boc & {$\left[\mathrm{Rh}(\mathrm{acac})\left(\mathrm{C}_{2} \mathrm{H}_{4}\right)_{2}\right]$} & $(S)$-BINAP & -- & -- $^{[\mathrm{a}]}$ \\
2 & $\mathrm{Z}\left(\mathrm{NO}_{2}\right)$ & $\mathrm{H}$ & {$\left[\mathrm{Rh}(\mathrm{acac})\left(\mathrm{C}_{2} \mathrm{H}_{4}\right)_{2}\right]$} & $(S)$-BINAP & -- & - - $^{[\mathrm{a}]}$ \\
3 & Boc-Phe & $\mathrm{H}$ & {$\left[\mathrm{Rh}(\mathrm{acac})\left(\mathrm{C}_{2} \mathrm{H}_{4}\right)_{2}\right]$} & $(S)$-BINAP & $\mathbf{4 a}$ & 40 \\
4 & Boc & $\mathrm{Boc}$ & {$\left[\mathrm{Rh}(\mathrm{COD})_{2}\right] \mathrm{BF}_{4}$} & --- & $\mathbf{3 a}$ & 70 \\
5 & $\mathrm{Z}\left(\mathrm{NO}_{2}\right)$ & $\mathrm{Boc}$ & {$\left[\mathrm{Rh}(\mathrm{COD})_{2}\right] \mathrm{BF}_{4}$} & --- & $\mathbf{5}$ & 60 \\
6 & Tos & $\mathrm{Boc}$ & {$\left[\mathrm{Rh}(\mathrm{COD})_{2}\right] \mathrm{BF}_{4}$} & --- & -- & [a] $^{[\mathrm{a}}$ \\
7 & $\mathrm{Z}\left(\mathrm{NO}_{2}\right)$ & $\mathrm{H}$ & {$\left[\mathrm{Rh}(\mathrm{COD})_{2}\right] \mathrm{BF}_{4}$} & -- & $\mathbf{6}$ & 85 \\
8 & Boc-Phe & $\mathrm{H}$ & {$\left[\mathrm{Rh}(\mathrm{COD})_{2}\right] \mathrm{BF}_{4}$} & --- & $\mathbf{4 a}$ & 50 \\
9 & Boc $-\mathrm{Ala}$ & $\mathrm{Boc}$ & {$\left[\mathrm{Rh}(\mathrm{COD})_{2}\right] \mathrm{BF}_{4}$} & --- & $\mathbf{8}$ & 17 \\
10 & Boc-Ala & $\mathrm{H}$ & {$\left[\mathrm{Rh}(\mathrm{COD})_{2}\right] \mathrm{BF}_{4}$} & --- & $\mathbf{7}$ & 72 \\
\hline
\end{tabular}

${ }^{[\mathrm{a}]}$ no product isolated.

From the results obtained, it is possible to conclude that the catalytic system $\left[\mathrm{Rh}(\mathrm{COD})_{2}\right] \mathrm{BF}_{4} /(S)$-BINAP failed to give the $\beta$ naphthylalanines when the substrates were the methyl esters of $\mathrm{N}, \mathrm{N}$-diprotected and $\mathrm{N}$-monoprotected dehydroalanines. In the case of the methyl ester of the dipeptide $N$-tert-butoxycarbonyl 
phenylalanyldehydroalanine (Boc-Phe- $\Delta$ Ala-OMe) it was possible to isolate the corresponding $\beta$-naphthylalanine derivative in $40 \%$ yield. In view of these results it was decided to change the catalyst to $\left[\mathrm{Rh}(\mathrm{COD})_{2}\right] \mathrm{BF}_{4}$. The $\beta$-naphthylalanines were obtained in good yields using the methyl esters of $N, N$-diacyl and $N$ acyldehydroalanines as substrates, except when one of the protecting groups was the $p$-toluenesulfonyl group. $\mathrm{N}, \mathrm{N}$ Diacyldehydrodipeptides were found to be poor acceptors in this type of reaction. In view of these results several $\beta$-arylalanines were prepared using as substrates the methyl ester of $N, N$-tertbutoxycarbonyldehydroalanine $\left(\mathrm{Boc}_{2}-\Delta \mathrm{Ala}-\mathrm{OMe}\right)$ and Boc-Phe$\Delta \mathrm{Ala}-\mathrm{OMe}$, and several arylboronic acids with $\left[\mathrm{Rh}(\mathrm{COD})_{2}\right] \mathrm{BF}_{4}$ as catalyst (Scheme 2, Table 2).

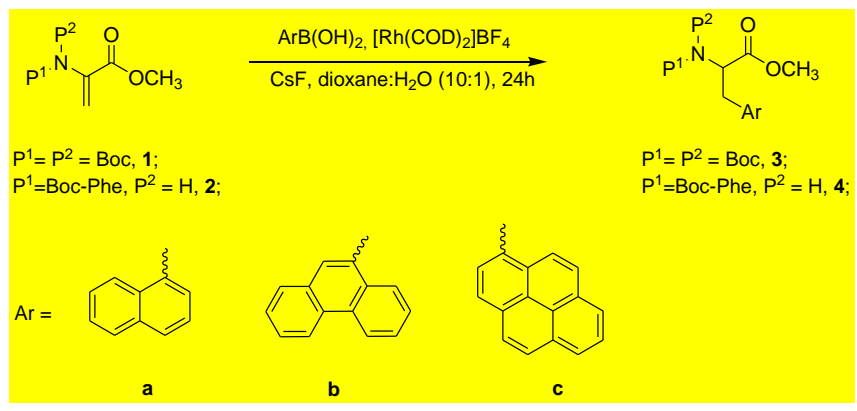

Scheme 2. Synthesis of $\beta$-arylalanine derivatives.

Table 2. Yields obtained in the synthesis of several $\beta$-arylalanine derivatives.

\begin{tabular}{lll}
\hline Substrate & Product & Yield / \%
\end{tabular}

1

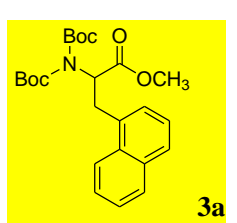

1

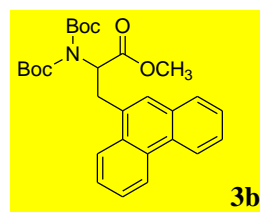

1

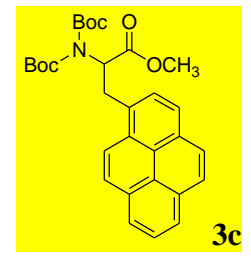

2

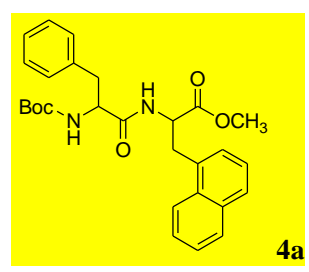

2

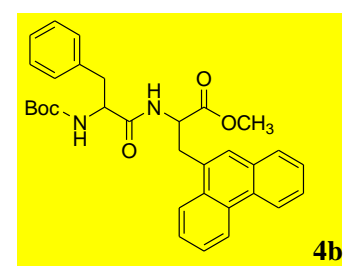

2

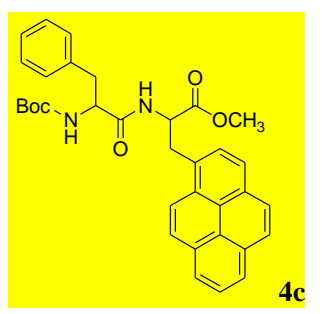

The absorption and fluorescence properties of the $\beta$-arylalanine derivatives 3a-c and 4a-c were studied in three solvents of different polarity (cyclohexane, acetonitrile and ethanol). The absorption $\left(\lambda_{\mathrm{abs}}\right)$ and emission maximum wavelengths $\left(\lambda_{\mathrm{em}}\right)$, molar absorption coefficients $(\varepsilon)$ and fluorescence quantum yields $\left(\Phi_{\mathrm{F}}\right)$ are presented in Tables 3 and 4 . The normalized absorption and fluorescence spectra of compounds 3a-c and 4a-c are shown in Figures 1 and 2.

All compounds present relatively high molar absorption coefficients at the lowest energy maximum $\left(\varepsilon \geq 3.4 \times 10^{3} \mathrm{M}^{-1} \mathrm{~cm}^{-1}\right)$ in all solvents studied (Tables 3 and 4 ), pointing to $\pi \rightarrow \pi^{*}$ transitions. The $\varepsilon$ values are significantly lower for compounds with a naphthyl group (3a, 4a) and a phenanthrenyl group (3b, $\mathbf{4 b})$. In fact, pyrene has a much higher molar absorption coefficient $\left(\varepsilon=54000 \mathrm{M}^{-1} \mathrm{~cm}^{-1}\right.$ at $\left.335 \mathrm{~nm}^{[4]}\right)$ than naphthalene (ca. $6000 \mathrm{M}^{-1}$ $\mathrm{cm}^{-1}$ at $\left.275 \mathrm{~nm}^{[4]}\right)$ and phenanthrene $\left(\varepsilon \sim 14000 \mathrm{M}^{-1} \mathrm{~cm}^{-1}\right.$ at 292 $\left.\mathrm{nm}^{[5]}\right)$, justifying this behaviour. A methyl ester group is present in all compounds and it is known that many carbonyl compounds present a low-lying $\mathrm{n} \rightarrow \pi^{*}$ state. The $\pi \rightarrow \pi^{*}$ and $\mathrm{n} \rightarrow \pi^{*}$ electronic transitions can be nearby in energy, resulting in state-mixing. ${ }^{[6]}$ The relatively high values of the molar absorption coefficient can be explained by a predominance of $\pi \rightarrow \pi^{*}$ character in these compounds (Tables 3 and 4).

Emission spectra of compounds 3a-c and 4a-c also resemble those of the pure fluorophores. ${ }^{[4]}$ In fact, the absence of an $\alpha, \beta$ double bond in these compounds does not allow conjugation between the aromatic moieties (in 4a-c) and the carbonyl groups (in all compounds), as previously observed for other $\beta, \beta$ diarylalanine compounds. ${ }^{[8]}$ 
Table 3. Maximum absorption ( $\left.\lambda_{\text {abs }}\right)$ and emission wavelengths $\left(\lambda_{\mathrm{em}}\right)$, molar absorption coefficients $(\varepsilon)$ and fluorescence quantum yields $\left(\Phi_{\mathrm{F}}\right)$ for compounds 3a, 3b and $\mathbf{3 c}$ in cyclohexane $(\mathrm{CyHx})$, acetonitrile $(\mathrm{ACN})$ and ethanol $(\mathrm{EtOH})$

\begin{tabular}{|c|c|c|c|c|c|c|c|c|c|}
\hline \multirow[t]{2}{*}{ Solvent } & \multicolumn{3}{|c|}{$\lambda_{\text {abs }}(\mathrm{nm})\left(\varepsilon / 10^{4} \mathrm{M}^{-1} \mathrm{~cm}^{-1}\right)$} & \multicolumn{3}{|l|}{$\lambda_{\mathrm{em}}(\mathrm{nm})$} & \multicolumn{3}{|l|}{$\Phi_{\mathrm{F}}^{[\mathrm{a}]}$} \\
\hline & $3 \mathbf{a}$ & $3 b$ & $3 c$ & $3 \mathbf{a}$ & $3 \mathbf{b}$ & $3 c$ & $3 \mathbf{a}$ & $\mathbf{3 b}$ & $3 c$ \\
\hline СyHx & $\begin{array}{l}292(0.41), \\
283(0.57), \\
273(0.49), \\
225(6.27)\end{array}$ & $\begin{array}{l}298(0.53), 286(0.47), \\
275(0.67), 254(3.10), \\
249(2.68) s h \\
209(2.19)\end{array}$ & $\begin{array}{l}343(3.08), 327(2.07), \\
313(0.83), 276(3.06), \\
266(1.76), 256(0.80), \\
243(4.83), \\
236(3.03) s h\end{array}$ & $\begin{array}{l}317,327, \\
340,352, \\
371 s h\end{array}$ & $\begin{array}{l}352,359 s h \\
370,390 \\
411 s h\end{array}$ & $\begin{array}{l}376,383,387, \\
393,397,404 s h, \\
422 s h\end{array}$ & 0.13 & 0.14 & 0.64 \\
\hline $\mathrm{ACN}$ & $\begin{array}{l}292(0.44), \\
282(0.64), \\
273(0.56), \\
224(6.22)\end{array}$ & $\begin{array}{l}298 \text { (0.59), } 286(0.54), \\
275(0.73), 253(3.44), \\
248(2.97) s h \\
211(2.00)\end{array}$ & $\begin{array}{l}342(3.75), 326(2.56), \\
313(1.06), 276(4.25), \\
265(2.87), 253(3.79), \\
243(8.04), \\
235(4.99) s h\end{array}$ & $\begin{array}{l}319,325, \\
340,353, \\
372 s h\end{array}$ & $\begin{array}{l}352,359 s h \\
370,389 \\
411 s h\end{array}$ & $\begin{array}{l}376,383,387, \\
393,397,404 s h, \\
424 s h\end{array}$ & 0.10 & 0.08 & 0.61 \\
\hline $\mathrm{EtOH}$ & $\begin{array}{l}292(0.52), \\
282(0.68), \\
272(0.59), \\
224(6.56)\end{array}$ & $\begin{array}{l}297(0.79), 285(0.79), \\
275(1.01), 253(3.74), \\
248(3.25) s h \\
211(2.59)\end{array}$ & $\begin{array}{l}342(2.96), 326(2.01), \\
313(0.86), 276(3.14), \\
265(1.90), 255(1.21), \\
242(5.07), \\
235(3.20) s h\end{array}$ & $\begin{array}{l}318,326, \\
340,351, \\
372 s h\end{array}$ & $\begin{array}{l}352,359 s h \\
369,389, \\
412 s h\end{array}$ & $\begin{array}{l}376,383,387, \\
393,397,405 s h, \\
422 s h\end{array}$ & 0.19 & 0.15 & 0.57 \\
\hline
\end{tabular}

${ }^{[a]}$ relative to naphthalene in cyclohexane $\left(\Phi_{\mathrm{F}}=0.23 \text { at } 25^{\circ} \mathrm{C}\right)^{[4]}$ for $\mathbf{3 a}$ and $\mathbf{3 b}$ and relative to anthracene in ethanol $\left(\Phi_{\mathrm{F}}=0.27 \text { at } 25^{\circ} \mathrm{C}\right)^{[7]}$ for $\mathbf{3 c} ; s h$ : shoulder.

Table 4. Maximum absorption ( $\left.\lambda_{\text {abs }}\right)$ and emission wavelengths $\left(\lambda_{\text {em }}\right)$, molar absorption coefficients $(\varepsilon)$ and fluorescence quantum yields $\left(\Phi_{\mathrm{F}}\right)$ for compounds $\mathbf{4 a}, \mathbf{4 b}$ and $\mathbf{4 c}$ in cyclohexane $(\mathrm{CyHx})$, acetonitrile $(\mathrm{ACN})$ and ethanol $(\mathrm{EtOH})$

\begin{tabular}{|c|c|c|c|c|c|c|c|c|c|}
\hline \multirow[t]{2}{*}{ Solvent } & \multicolumn{3}{|c|}{$\lambda_{\text {abs }}(\mathrm{nm})\left(\varepsilon / 10^{4} \mathrm{M}^{-1} \mathrm{~cm}^{-1}\right)$} & \multicolumn{3}{|l|}{$\lambda_{\mathrm{em}}(\mathrm{nm})$} & \multicolumn{3}{|c|}{$\Phi_{\mathrm{F}}^{[\mathrm{a}]}$} \\
\hline & $4 a$ & $4 b$ & $4 c$ & $4 a$ & $4 b$ & $4 c$ & $4 a$ & $4 b$ & $4 c$ \\
\hline $\mathrm{CyHx}$ & $\begin{array}{l}293(0.34), \\
283(0.53), \\
274(0.49), \\
226(5.86)\end{array}$ & $\begin{array}{l}299 \text { (0.96), } 288 \text { (0.87), } \\
277(1.12), 255 \text { (4.92), } \\
249 \text { (4.10) sh, } \\
221 \text { (2.04) sh, } \\
211 \text { (2.92) }\end{array}$ & $\begin{array}{l}344(3.52), 327(2.37), \\
313(0.94), 277(3.41), \\
266(1.95), 256(0.85), \\
244(5.10), \\
236(3.13) s h\end{array}$ & $\begin{array}{l}317,326, \\
340,351 s h, \\
374 s h\end{array}$ & $\begin{array}{l}352,361 s h, \\
370,389, \\
410 s h\end{array}$ & $\begin{array}{l}376,383,388, \\
393,397,421 s h\end{array}$ & 0.12 & 0.13 & 0.48 \\
\hline $\mathrm{ACN}$ & $\begin{array}{l}291(0.39), \\
283(0.57), \\
273(0.48), \\
224(6.35)\end{array}$ & $\begin{array}{l}298 \text { (0.90), } 286(0.81), \\
276(1.02), 254 \text { (4.84), } \\
249 \text { (4.20) sh, } \\
221(2.28) s h \\
211(3.35)\end{array}$ & $\begin{array}{l}343(3.50), 327(2.41), \\
313(0.99), 276(3.52), \\
265(2.02), 256(0.95), \\
243(5.58), \\
235(3.57) s h\end{array}$ & $\begin{array}{l}319,325, \\
340,354 s h, \\
372 s h\end{array}$ & $\begin{array}{l}351,360 s h, \\
369,389, \\
409 s h\end{array}$ & $\begin{array}{l}376,382,387, \\
393,398,419 \mathrm{~s} h\end{array}$ & 0.06 & 0.06 & 0.47 \\
\hline $\mathrm{EtOH}$ & $\begin{array}{l}291(0.50), \\
282(0.71), \\
273(0.61), \\
225(7.07)\end{array}$ & $\begin{array}{l}298 \text { (1.02), } 286 \text { (0.94), } \\
276(1.19), 254 \text { (5.25), } \\
248(4.44) s h, \\
222(2.66) s h, \\
211(3.91)\end{array}$ & $\begin{array}{l}343(3.27), 327(2.30), \\
313(1.00), 276(3.42), \\
265(2.07), 256(1.06), \\
243(5.33), \\
235(3.46) s h\end{array}$ & $\begin{array}{l}319,326, \\
340,352 s h \\
375 s h\end{array}$ & $\begin{array}{l}351,357 s h, \\
369,389, \\
409 s h\end{array}$ & $\begin{array}{l}376,382,387, \\
393,397,420 s h\end{array}$ & 0.13 & 0.10 & 0.43 \\
\hline
\end{tabular}

All compounds present reasonable to high fluorescence quantum yields in all solvents studied (Tables 3 and 4 ). The $\Phi_{\mathrm{F}}$ values are similar to those of the pure polycyclic aromatic hydrocarbons (PAHs) at room temperature $\left(\Phi_{\mathrm{F}}\right.$ values are 0.23 in cyclohexane and 0.21 in ethanol for naphthalene; 0.13 for phenanthrene and 0.65 for pyrene in both ethanol and cyclohexane $\left.{ }^{[4,9]}\right)$. A decrease in $\Phi_{\mathrm{F}}$ values relative to the PAHs was expected, considering the flexibility of the chain linked to the fluorescent moieties in the new compounds, which favours the non-radiative deactivation pathways As expected, compounds 4a-c exhibit lower fluorescence quantum yields than the corresponding analogues in the 3a-c series, indicating a larger deactivation by non-radiative transitions, as would also expected. This effect is especially significant for compound $\mathbf{4 c}$, due to the extremely long excited state lifetime of the pyrene moiety (450 ns for pyrene in cyclohexane and $410 \mathrm{~ns}$ in ethanol $^{[9]}$ ).

It is well known that the ratio of intensities between the first and the third pyrene vibronic bands, $I_{1} / I_{3}$, is solvent dependent (the pyrene polarity scale), rising with the increase of solvent polarity. ${ }^{[10]}$ Similarly, compounds $3 \mathbf{c}$ and $4 \mathbf{c}$ exhibit a solvent sensitive $I_{1} / I_{3}$ ratio (Table 5), following the observed behaviour in the pyrene fluorescence spectrum, despite a lower degree of sensitivity. In fact, the groups in close proximity to the pyrenyl moiety in compounds $\mathbf{3 c}$ and $\mathbf{4 c}$ influence the local polarity, and thus the relative intensities of the vibronic bands in the emission spectra.

The generally high fluorescence quantum yields of these compounds make them good candidates to be used as fluorescence markers. In particular, compounds $\mathbf{3 c}$ and $\mathbf{4 c}$ may be useful as probes for peptides and proteins, since both compounds can be excited without simultaneous excitation of other aromatic amino acids (phenylalanine, tyrosine and tryptophan) that absorb light at wavelengths lower than $300 \mathrm{~nm} .{ }^{[1,12]}$ The solvent sensitivity of the vibrational structure of their emission spectrum make compounds $3 \mathbf{c}$ and $\mathbf{4 c}$ also promising as polarity probes. 


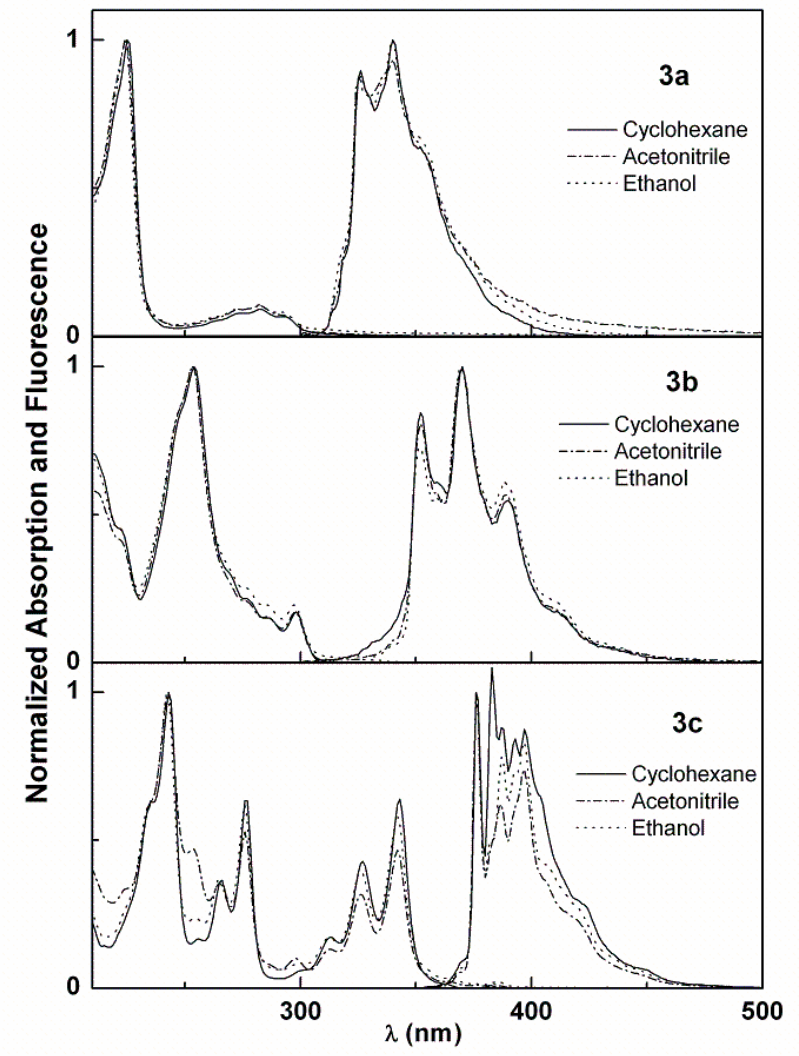

Figure 1. Normalized absorption and fluorescence spectra of solutions of compounds 3a-c $\left(10^{-5} \mathrm{M}\right.$ for absorption and $10^{-6} \mathrm{M}$ for emission) in cyclohexane, acetonitrile and ethanol $\left(\lambda_{\mathrm{exc}}=270 \mathrm{~nm}\right.$ for $\mathbf{3 a}$ and $\mathbf{3 b}$ and $\lambda_{\mathrm{exc}}=345 \mathrm{~nm}$ for $\mathbf{3 c}$ ).

Table 5 . Intensity ratio between the first and third vibronic bands, $I_{1} / I_{3}$, of the fluorescence spectrum for compounds $\mathbf{3 c}$ and $\mathbf{4 c}$. Values for pyrene are also shown for comparison.

\begin{tabular}{llll}
\hline Solvent & \multicolumn{3}{c}{$\mathbf{I}_{\mathbf{1}} / \mathbf{I}_{\mathbf{3}}$} \\
& $\mathbf{3 c}$ & $\mathbf{4 c}$ & Pyrene $^{[\mathbf{1 0}]}$ \\
\hline $\mathrm{CyHx}$ & 0.92 & 1.18 & 0.58 \\
$\mathrm{EtOH}$ & 1.28 & 1.56 & 1.18 \\
$\mathrm{ACN}$ & 1.61 & 2.08 & 1.79 \\
\hline
\end{tabular}

\section{Conclusions}

Several fluorescent $\beta$-arylalanines were prepared in good to high yields using a rhodium catalysed conjugate addition of aryl boronic acids to $\mathrm{N}, \mathrm{N}$-diprotected dehydroalanine derivatives. This reaction was also applied successfully to dipeptides with a dehydroalanine residue. The photophysical properties of these compounds were studied in solvents with different polarities. The results show that all compounds prepared, due to the generally high fluorescence quantum yields, can be used as fluorescent markers. The $\beta$-pyrenylalanine derivatives may be used as probes for peptides and proteins since these compounds can be excited without simultaneous excitation of other aromatic amino acids.

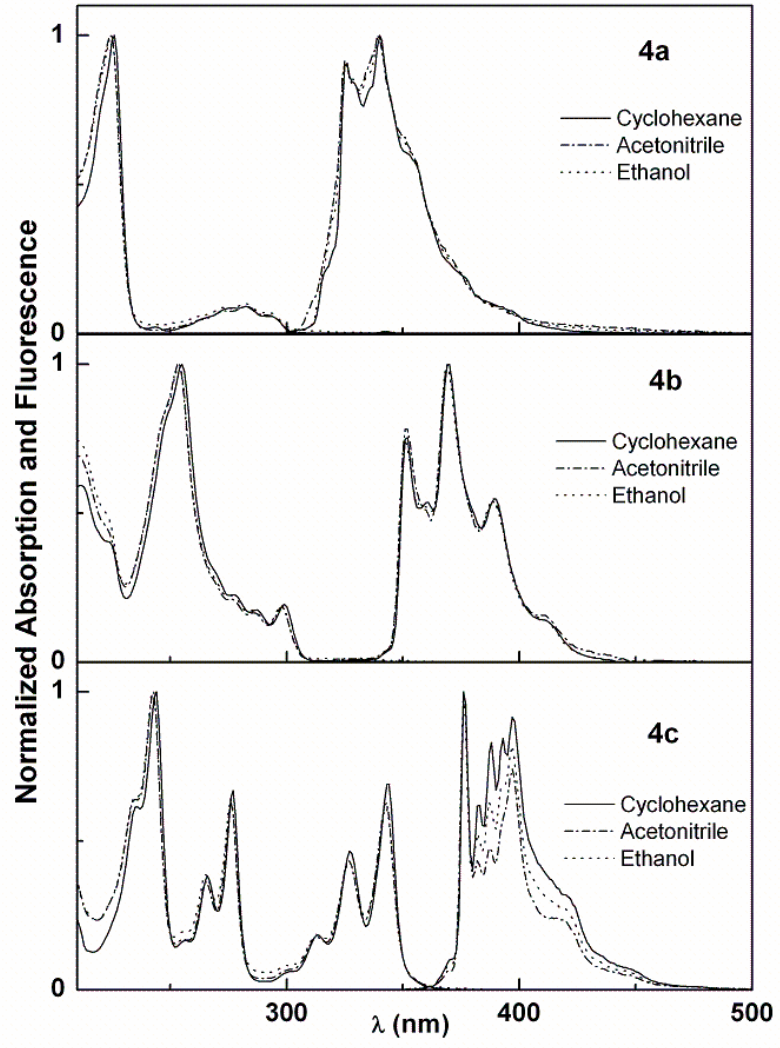

Figure 2. Normalized absorption and fluorescence spectra of solutions of compounds 4a-c $\left(10^{-5} \mathrm{M}\right.$ for absorption and $10^{-6} \mathrm{M}$ for emission) in cyclohexane, acetonitrile and ethanol $\left(\lambda_{\mathrm{exc}}=270 \mathrm{~nm}\right.$ for $\mathbf{4 a}$ and $\mathbf{4 b}$ and $\lambda_{\mathrm{exc}}=345 \mathrm{~nm}$ for $\mathbf{4 c}$ ).

\section{Experimental Section}

Melting points $\left({ }^{\circ} \mathrm{C}\right)$ were determined in a a Buchi 535 melting point apparatus and are uncorrected. ${ }^{1} \mathrm{H}$ and ${ }^{13} \mathrm{C}$ NMR spectra were recorded on a Bruker AV300 spectrometer at 300 and $75.4 \mathrm{MHz}$, respectively or on a Bruker AVANCE 400 spectrometer at 400 and $100.6 \mathrm{MHz}$, respectively. ${ }^{1} \mathrm{H}-{ }^{1} \mathrm{H}$ spin-spin decoupling and DEPT $\theta 45^{\circ}$ were used. Chemical shifts are given in ppm and coupling constants in Hz. MS and HRMS data were recorded using a Bruker ESI-TOF or ESI-QTOF Mass Spectrometry Service at the University of Bath.

The reactions were monitored by thin layer chromatography (TLC). Column chromatography was performed on Macherey-Nagel silica gel 230400 mesh. Petroleum ether refers to the boiling range $40-60{ }^{\circ} \mathrm{C}$. When solvent gradient was used, the increase of polarity was made from neat petroleum ether to mixtures of diethyl ether/petroleum ether, increasing $10 \%$ of diethyl ether each time until the isolation of the product.

Spectroscopic measurements: The solutions were prepared using spectroscopic grade solvents. All measurements were performed at $25.0 \pm 0.5^{\circ} \mathrm{C}$. Absorption spectra were recorded in a Shimadzu UV-3101PC UV-Vis-NIR spectrophotometer. Fluorescence measurements were performed using a Fluorolog 3 spectrofluorimeter, equipped with double monochromators in both excitation and emission and a temperature controlled cuvette holder. Fluorescence spectra were corrected for the instrumental response of the system. For fluorescence quantum yield determination, the solutions were previously bubbled for 30 minutes with ultrapure nitrogen. The fluorescence quantum yields $\left(\Phi_{\mathrm{s}}\right)$ were determined using the standard method (equation 1$)^{[13,14]}$

$\Phi_{\mathrm{s}}=\frac{A_{\mathrm{r}} F_{\mathrm{s}} n_{\mathrm{S}}^{2}}{A_{\mathrm{s}} F_{\mathrm{r}} n_{\mathrm{r}}^{2}} \Phi_{\mathrm{r}}$ 
where $A$ is the absorbance at the excitation wavelength, $F$ the integrated emission area and $n$ the refraction index of the solvents used. Subscripts refer to the reference (r) or sample (s) compound. The excitation wavelengths of the samples were chosen to ensure that there is a linear relationship between the intensity of emitted light and the concentration of the absorbing/emitting species $(\mathrm{A} \leq 0.05)$.

Synthesis of dehydroalanine derivatives: The synthesis of these compounds was described elsewhere. ${ }^{[3 a, 3 e]}$

\section{General procedure for the rhodium-catalyzed addition of arylboronic acids to dehydroalanine derivatives}

An oven dried Shlenk tube was charged with dehydroalanine derivative $(0.2$ $\mathrm{mmol})$, boronic acid (4 equiv., $0.8 \mathrm{mmol}),\left[\mathrm{Rh}\left(\mathrm{COD}_{2}\right)\right] \mathrm{BF}_{4}(5 \mathrm{~mol} \%, 0,01$ $\mathrm{mmol}), \mathrm{CsF}$ (3 equiv., $0.6 \mathrm{mmol}$ ), anhydrous 1,4-dioxane $(2 \mathrm{~mL})$ and water $(0.2 \mathrm{~mL})$. The reaction mixture was heated to $110^{\circ} \mathrm{C}$ for 24 hours under an atmosphere of nitrogen. The reaction was cooled to room temperature and the solvent evaporated. The resulting residue was dissolved in ethyl acetate $(20 \mathrm{~mL})$ and washed with water $(2 \times 20 \mathrm{~mL})$ and brine $(2 \times 20 \mathrm{~mL})$. The organic layer was dried over $\mathrm{MgSO} 4$ and concentrated in vacuo. The resulting residue was purified by column chromatography.

Synthesis of methyl 2-[bis(tert-butoxycarbonyl)amino]-3-(naphthalen-1yl)propanoate 3a:

The general procedure described above was followed with compound $\mathbf{1}(0.2$ $\mathrm{mmol}, 60.5 \mathrm{mg})$ and 1-naphthaleneboronic acid $(0.8 \mathrm{mmol}, 138 \mathrm{mg})$ to give compound 3a $(60.2 \mathrm{mg}, 70 \%)$ as an oil. ${ }^{1} \mathrm{H}$ NMR $\left(300 \mathrm{MHz}, \mathrm{CDCl}_{3}\right)$ $\delta$ : $1.12\left(\mathrm{~s}, 18 \mathrm{H}, \mathrm{CH}_{3}\right), 3.48-3.56\left(\mathrm{dd}, 1 \mathrm{H}, J=11.1\right.$ and $\left.3.3 \mathrm{~Hz}, \mathrm{CH}_{2}\right), 3.73$ (s, $3 \mathrm{H}, \mathrm{OCH}_{3}$ ), 3.96-4.02 (dd, $1 \mathrm{H}, J=3.6$ and $10.8 \mathrm{~Hz}, \mathrm{CH}_{2}$ ), 5.18-5.23 (dd, $1 \mathrm{H}, J=3.9$ and $6.9 \mathrm{~Hz}, \mathrm{CH}), 7.21(\mathrm{~d}, 1 \mathrm{H}, J=9.6 \mathrm{~Hz}, \mathrm{HAr}), 7.31$ (t, 1 $\mathrm{H}, J=8.1 \mathrm{~Hz}, \mathrm{HAr}), 7.37-7.47$ (m, $2 \mathrm{H}, \mathrm{HAr}), 7.67$ (d, $1 \mathrm{H}, J=8.1 \mathrm{~Hz}$, HAr), 7.77 (d, $1 \mathrm{H}, J=6.9 \mathrm{~Hz}, \mathrm{HAr}), 7.96$ (d, $1 \mathrm{H}, J=7.8 \mathrm{~Hz}, \mathrm{HAr}$ ) ppm. ${ }^{13} \mathrm{C}$ NMR $\left(75.5 \mathrm{MHz}, \mathrm{CDCl}_{3}\right) \delta$ : $27.60\left(\mathrm{CH}_{3}\right), 33.07\left(\mathrm{CH}_{2}\right), 52.42\left(\mathrm{OCH}_{3}\right)$, $59.10(\mathrm{CH}), 82.89\left[\mathrm{C}\left(\mathrm{CH}_{3}\right)_{3}\right], 123.40(\mathrm{CH}), 125.57(\mathrm{CH}), 125.61(\mathrm{CH})$, $126.21(\mathrm{CH}), 127.51(\mathrm{CH}), 128.14(\mathrm{CH}), 128.86(\mathrm{CH}), 132.14(\mathrm{C}), 133.87$ (C), $133.91(\mathrm{C}), 151.27(\mathrm{C}=\mathrm{O}), 170.95(\mathrm{C}=\mathrm{O})$ ppm. HMRS (ESI): calcd. for $\mathrm{C}_{24} \mathrm{H}_{31} \mathrm{NNaO}_{6} 452.20491$; found 452.2032 .

Synthesis of methyl 2-[bis(tert-butoxycarbonyl)amino]-3-(phenanthren-9yl)propanoate $\mathbf{3 b}$ :

The general procedure described above was followed with compound $\mathbf{1}(0.2$ mmol, $60.5 \mathrm{mg}$ ) and 9-phenanthraneboronic acid $(0.8 \mathrm{mmol}, 177 \mathrm{mg})$ to give compound $\mathbf{3 b}(66.0 \mathrm{mg}, 69 \%)$ as an oil. ${ }^{1} \mathrm{H}$ NMR $\left(300 \mathrm{MHz}, \mathrm{CDCl}_{3}\right.$ ) $\delta$ : $1.07\left(\mathrm{~s}, 18 \mathrm{H}, \mathrm{CH}_{3}\right), 3.51-3.59\left(\mathrm{dd}, 1 \mathrm{H}, J=10.8\right.$ and $\left.3.6 \mathrm{~Hz}, \mathrm{CH}_{2}\right), 3.75$ (s, $3 \mathrm{H}, \mathrm{OCH}_{3}$ ), 4.03-4.09 (dd, $1 \mathrm{H}, J=3.6$ and $10.8 \mathrm{~Hz}, \mathrm{CH}_{2}$ ), 5.23-5.28 (dd, $1 \mathrm{H}, J=3.9$ and $6.9 \mathrm{~Hz}, \mathrm{CH}), 7.47-7.59$ (m, $5 \mathrm{H}, \mathrm{HAr}), 7.72$ (d, $1 \mathrm{H}, J$ $=7.5 \mathrm{~Hz}, \mathrm{HAr}), 8.00-8.04(\mathrm{~m}, 1 \mathrm{H}, \mathrm{HAr}), 8.57$ (d, $1 \mathrm{H}, J=7.8 \mathrm{~Hz}, \mathrm{HAr})$, 8.64-8.67 (m, $1 \mathrm{H}, \mathrm{HAr})$ ppm. ${ }^{13} \mathrm{C} \mathrm{NMR}\left(75.5 \mathrm{MHz}, \mathrm{CDCl}_{3}\right) \delta: 27.54$ $\left(\mathrm{CH}_{3}\right), 33.56\left(\mathrm{CH}_{2}\right), 52.48\left(\mathrm{OCH}_{3}\right), 58.63(\mathrm{CH}), 82.88\left[\mathrm{C}\left(\mathrm{CH}_{3}\right)_{3}\right], 122.33$ $(\mathrm{CH}), 123.33(\mathrm{CH}), 123.98(\mathrm{CH}), 126.37(\mathrm{CH}), 126-39(\mathrm{CH}), 126.66(\mathrm{CH})$, $126.90(\mathrm{CH}), 128.28(\mathrm{CH}), 128.79(\mathrm{CH}), 130.04(\mathrm{C}), 130.74(\mathrm{C}), 131.06$ (C), $131.61(\mathrm{C}), 131.98(\mathrm{C}), 151.47(\mathrm{C}=\mathrm{O}), 170.97(\mathrm{C}=\mathrm{O})$ ppm. HMRS (ESI): calcd. for $\mathrm{C}_{28} \mathrm{H}_{33} \mathrm{NNaO}_{6} 502.22056$; found 502.2245.

Synthesis of methyl 2-[bis(tert-butoxycarbonyl)amino]-3-(pyren-1yl)propanoate $\mathbf{3 c}$ :

The general procedure described above was followed with compound $\mathbf{1}(0.2$ $\mathrm{mmol}, 60.5 \mathrm{mg})$ and 1-pyreneboronic acid $(0.8 \mathrm{mmol}, 197 \mathrm{mg})$ to give compound 3c $(67.0 \mathrm{mg}, 67 \%)$ as an oil. ${ }^{1} \mathrm{H}$ NMR $\left(300 \mathrm{MHz}, \mathrm{CDCl}_{3}\right) \delta$ : $1.02\left(\mathrm{~s}, 18 \mathrm{H}, \mathrm{CH}_{3}\right), 3.76\left(\mathrm{~s}, 3 \mathrm{H}, \mathrm{OCH}_{3}\right), 3.84-3.92$ (dd, $1 \mathrm{H}, J=10.5$ and $3.6 \mathrm{~Hz}, \mathrm{CH}_{2}$ ), 4.16-4.22 (dd, $1 \mathrm{H}, J=4.2$ and $10.2 \mathrm{~Hz}, \mathrm{CH}_{2}$ ), 5.29-5.34 (dd, $1 \mathrm{H}, J=4.2$ and $6.6 \mathrm{~Hz}, \mathrm{CH}), 7.78(\mathrm{~d}, 1 \mathrm{H}, J=7.8 \mathrm{~Hz}, \mathrm{HAr}), 7.89-7.95$ (m,
$3 \mathrm{H}, \mathrm{HAr}), 8.03$ (d, $2 \mathrm{H}, J=8.1 \mathrm{~Hz}, \mathrm{HAr}), 8.10$ (d, $2 \mathrm{H}, J=7.8 \mathrm{~Hz}, \mathrm{HAr}$ ), 8.22 (d, $1 \mathrm{H}, J=9.3 \mathrm{~Hz}, \mathrm{HAr}) \mathrm{ppm} .{ }^{13} \mathrm{C} \mathrm{NMR}\left(75.5 \mathrm{MHz}, \mathrm{CDCl}_{3}\right) \delta: 27.50$ $\left(\mathrm{CH}_{3}\right), 33.42\left(\mathrm{CH}_{2}\right), 52.46\left(\mathrm{OCH}_{3}\right), 59.85(\mathrm{CH}), 82.87\left[\mathrm{C}\left(\mathrm{CH}_{3}\right)_{3}\right], 123.13$ $(\mathrm{CH}), 124.84(\mathrm{CH}), 124.90(\mathrm{CH}), 125.00(\mathrm{C}), 125.03(\mathrm{CH}), 125.84(\mathrm{CH})$ $126.98(\mathrm{CH}), 127.44(\mathrm{CH}), 127.68(\mathrm{CH}), 128.63(\mathrm{CH}), 129.52(\mathrm{C}), 130.46$ (C), 130.85 (C), 131.30 (C), 131.88 (C), $151.54(\mathrm{C}=\mathrm{O}), 170.93(\mathrm{C}=\mathrm{O}) \mathrm{ppm}$. HMRS (ESI): calcd. for $\mathrm{C}_{30} \mathrm{H}_{33} \mathrm{NNaO}_{6} 526.22056$; found 526.2205.

Synthesis of methyl 2-\{tert-butoxycarbonyl[(4nitrobenzyloxy)carbonyl]amino)-3-(naphthalen-1-yl\}propanoate 5:

The general procedure described above was followed with methyl 2-\{tertbutoxycarbonyl[(4-nitrobenzyloxy)carbonyl]amino $\}$ acrylate $(0.2 \mathrm{mmol}, 76$ $\mathrm{mg})$ and 1-naphthaleneboronic acid $(0.8 \mathrm{mmol}, 138 \mathrm{mg})$ to give compound $5(61.3 \mathrm{mg}, 60 \%)$ as an oil. ${ }^{1} \mathrm{H}$ NMR $\left(300 \mathrm{MHz}, \mathrm{CDCl}_{3}\right) \delta: 1.17(\mathrm{~s}, 9 \mathrm{H}$, $\mathrm{CH}_{3}$ ), 3.48-3.57 (dd, $1 \mathrm{H}, J=11.1$ and $\left.3.6 \mathrm{~Hz}, \mathrm{CH}_{2}\right), 3.72\left(\mathrm{~s}, 3 \mathrm{H}, \mathrm{OCH}_{3}\right)$, 3.98-4.04 (dd, $1 \mathrm{H}, J=3.9$ and $\left.10.5 \mathrm{~Hz}, \mathrm{CH}_{2}\right), 4.93(\mathrm{q}, 2 \mathrm{H}, J=13.5 \mathrm{~Hz}$, $\mathrm{CH}_{2}$ ), 5.26-5.31 (m, $\left.1 \mathrm{H}, \mathrm{CH}\right), 7.12-7.15$ (m, $\left.3 \mathrm{H}, \mathrm{HAr}\right), 7.26(\mathrm{t}, 1 \mathrm{H}, J=$ $7.2 \mathrm{~Hz}, \mathrm{HAr}$ ), 7.38-7.44 (m, $2 \mathrm{H}, \mathrm{HAr}), 7.65$ (d, $1 \mathrm{H}, J=8.1 \mathrm{~Hz}, \mathrm{HAr}$ ), 7.75-7.79 (m, 1 H, HAr), 7.90-7.94 (m, $1 \mathrm{H}, \mathrm{HAr}$ ), 8.05 (d, $2 \mathrm{H}, J=6.9 \mathrm{~Hz}$, HAr) ppm. ${ }^{13} \mathrm{C}$ NMR (75.5 MHz, $\left.\mathrm{CDCl}_{3}\right) \delta$ : $27.58\left(\mathrm{CH}_{3}\right), 32.80\left(\mathrm{CH}_{2}\right)$, $52.66\left(\mathrm{OCH}_{3}\right), 59.49(\mathrm{CH}), 66.89\left(\mathrm{CH}_{2}\right), 84.00\left[\mathrm{C}\left(\mathrm{CH}_{3}\right)_{3}\right], 123.16(\mathrm{CH})$, $123.67(\mathrm{CH}), 125.46(\mathrm{CH}), 125.76(\mathrm{CH}), 126.30(\mathrm{CH}), 127.71(\mathrm{CH})$, $128.05(\mathrm{CH}), 128.97(\mathrm{CH}), 131.91(\mathrm{C}), 133.37(\mathrm{C}), 133.82(\mathrm{C}), 142.37(\mathrm{C})$, $150.40(\mathrm{C}=\mathrm{O}), 153.20(\mathrm{C}=\mathrm{O}), 170.29(\mathrm{C}=\mathrm{O})$ ppm.HMRS (ESI): calcd. for $\mathrm{C}_{27} \mathrm{H}_{28} \mathrm{~N}_{2} \mathrm{NaO}_{8}$ 531.17434; found 531.1750.

Synthesis of methyl 3-(naphthalen-1-yl)-2-[(4 nitrobenzyloxy)carbonylamino]propanoate 6 :

The general procedure described above was followed with methyl 2-[(4nitrobenzyloxy)carbonylamino]acrylate $(0.2 \mathrm{mmol}, 56 \mathrm{mg})$ and 1 naphthaleneboronic acid $(0.8 \mathrm{mmol}, 138 \mathrm{mg})$ to give compound $6(69.5 \mathrm{mg}$, $85 \%$ ) as a white solid. M.p. 140.0-141.0 ${ }^{\circ} \mathrm{C}$ (from ethyl acetate/ n-hexane). ${ }^{1} \mathrm{H}$ NMR $\left(300 \mathrm{MHz}, \mathrm{CDCl}_{3}\right) \delta: 3.38-3.45(\mathrm{dd}, 1 \mathrm{H}, J=6.9$ and $7.2 \mathrm{~Hz}$, $\left.\mathrm{CH}_{2}\right), 3.54-3.60\left(\mathrm{~m}, 4 \mathrm{H}, \mathrm{OCH}_{3}\right.$ and $\left.\mathrm{CH}_{2}\right), 4.72(\mathrm{~d}, 1 \mathrm{H}, J=7.8 \mathrm{~Hz}, \mathrm{CH})$, 5.07 (s, $\left.2 \mathrm{H}, \mathrm{CH}_{2}\right), 5.29$ (d, $\left.1 \mathrm{H}, J=8.1 \mathrm{~Hz}, \mathrm{NH}\right), 7.14-7.19$ (m, $\left.2 \mathrm{H}, \mathrm{HAr}\right)$, 7.28-7.35 (m, 2 H, HAr), 7.42-7.46 (m, 2 H, HAr), 7.71 (d, $1 \mathrm{H}, J=8.4 \mathrm{~Hz}$, HAr), 7.78-7.82 (m, 1 H, HAr), 7.95-8.01 (m, 1 H, HAr), 8.12 (d, 2 H, $J=$ $8.7 \mathrm{~Hz}, \mathrm{HAr})$ ppm. ${ }^{13} \mathrm{C}$ NMR $\left(75.5 \mathrm{MHz}, \mathrm{CDCl}_{3}\right) \delta$ : $35.58\left(\mathrm{CH}_{2}\right), 54.48$ $\left(\mathrm{OCH}_{3}\right), 54.74(\mathrm{CH}), 65.34\left(\mathrm{CH}_{2}\right), 123.28(\mathrm{CH}), 123.75(\mathrm{CH}), 125.28(\mathrm{CH})$, $125.88(\mathrm{CH}), 126.45(\mathrm{CH}), 127.52(\mathrm{CH}), 128.00(\mathrm{CH}), 128.16(\mathrm{CH})$, 128.99 (CH), $132.00(\mathrm{C}), 132.08$ (C), 133.92 (C), 143.67 (C), 147.58 (C), $155.15(\mathrm{C}=\mathrm{O}), 172.20(\mathrm{C}=\mathrm{O}) \mathrm{ppm}$. HMRS (ESI): calcd. for $\mathrm{C}_{22} \mathrm{H}_{20} \mathrm{~N}_{2} \mathrm{NaO}_{6}$ 431.12191; found 431.1220 .

Synthesis of methyl 2-[2-(tert-butoxycarbonylamino)-3phenylpropanamido]-3-(naphthalen-1-yl)propanoate 4a:

The general procedure described above was followed with compound 2 ( 0.2 mmol, $70.0 \mathrm{mg}$ ) and 1-naphthaleneboronic acid $(0.8 \mathrm{mmol}, 138 \mathrm{mg})$ to give compound 4a (48.0 mg, 50\%) as a white solid. M.p. 139.0-140.0 ${ }^{\circ} \mathrm{C}$ (from ethyl acetate/ $\mathrm{n}$-hexane). ${ }^{1} \mathrm{H}$ NMR $\left(300 \mathrm{MHz}, \mathrm{CDCl}_{3}\right) \delta: 1.30\left(\mathrm{~s}, 9 \mathrm{H}, \mathrm{CH}_{3}\right)$, 2.87-2.98 (m, $\left.2 \mathrm{H}, \mathrm{CH}_{2}\right), 3.37-3.49\left(\mathrm{~m}, 5 \mathrm{H}, \mathrm{CH}_{2}\right.$ and $\left.\mathrm{OCH}_{3}\right), 4.25$ (br. s, 1 $\mathrm{H}, \mathrm{CH}), 4.79-4.86(\mathrm{~m}, 2 \mathrm{H}, \mathrm{CH}$ and $\mathrm{NH}), 6.23-6.39(\mathrm{dd}, 1 \mathrm{H}, J=7.5 \mathrm{~Hz}$, $\mathrm{NH}$ ), 7.00-7.30 (m, 7 H, HAr), 7.40-7.51 (m, $2 \mathrm{H}, \mathrm{HAr}), 7.68$ (d, $1 \mathrm{H}, J=$ $8.4 \mathrm{~Hz}, \mathrm{HAr}), 7.78$ (d, $1 \mathrm{H}, J=8.7 \mathrm{~Hz}, \mathrm{HAr}), 7.98(\mathrm{t}, 1 \mathrm{H}, J=8.7 \mathrm{~Hz}, \mathrm{HAr})$ ppm. ${ }^{13} \mathrm{C}$ NMR $\left(75.5 \mathrm{MHz}, \mathrm{CDCl}_{3}\right) \delta$ : $28.24\left(\mathrm{CH}_{3}\right), 35.41$ and $35.46\left(\mathrm{CH}_{2}\right)$, $38.37\left(\mathrm{CH}_{2}\right), 52.24\left(\mathrm{OCH}_{3}\right), 53.08$ and $53.26(\mathrm{CH}), 55.64(\mathrm{CH}), 80.23$ $\left[\mathrm{C}\left(\mathrm{CH}_{3}\right)_{3}\right], 123.37$ and $123.50(\mathrm{CH}), 125.28(\mathrm{CH}), 125.82$ and $125.86(\mathrm{CH})$, 126.38 and $126.48(\mathrm{CH}), 126.98(\mathrm{CH}), 127.41$ and $127.48(\mathrm{CH}), 128.04$ and $128.09(\mathrm{CH}), 128.64$ and $128.67(\mathrm{CH}), 128.92(\mathrm{CH}), 129.31$ and $129.37(\mathrm{CH}), 131.98$ and $132.04(\mathrm{C}), 132.08$ and $132.12(\mathrm{C}), 133.90(\mathrm{C})$, $136.49(\mathrm{C}), 155.28(\mathrm{C}=\mathrm{O}), 170.83$ and $170.96(\mathrm{C}=\mathrm{O}), 171.67$ and 171.97 $(\mathrm{C}=\mathrm{O})$ ppm. HMRS (ESI): calcd. for $\mathrm{C}_{28} \mathrm{H}_{32} \mathrm{~N}_{2} \mathrm{NaO}_{5}$ 499.22089; found 499.2251. 
Synthesis of methyl 2-[2-(tert-butoxycarbonylamino)-3phenylpropanamido]-3-(phenanthren-9-yl)propanoate $\mathbf{4 b}$ :

The general procedure described above was followed with compound $\mathbf{2}(0.2$ $\mathrm{mmol}, 70.0 \mathrm{mg})$ and 9 - phenanthraneboronic acid $(0.8 \mathrm{mmol}, 177 \mathrm{mg})$ to give compound $\mathbf{4 b}(57.0 \mathrm{mg}, 54 \%){ }^{[2 \mathrm{c}]}$

Synthesis of methyl 2-[2-(tert-butoxycarbonylamino)-3phenylpropanamido]-3-(pyren-1-yl)propanoate 4c:

The general procedure described above was followed with compound 2 (0.2 mmol, $70.0 \mathrm{mg})$ and 1-pyreneboronic acid $(0.8 \mathrm{mmol}, 197 \mathrm{mg})$ to give compound 4c (37.6 mg, 34\%) as a white solid. M.p. $185.0-186.0^{\circ} \mathrm{C}$ (from ethyl acetate/ n-hexane). ${ }^{1} \mathrm{H}$ NMR $\left(300 \mathrm{MHz} \mathrm{CDCl}_{3}\right) \delta: 1.15$ and 1.18 (s, 9 $\left.\mathrm{H}, \mathrm{CH}_{3}\right), 2.82-2.87\left(\mathrm{~m}, 2 \mathrm{H}, \mathrm{CH}_{2}\right), 3.36$ and $3.41\left(\mathrm{~s}, 3 \mathrm{H}, \mathrm{OCH}_{3}\right), 3.60-3.63$ (m, $2 \mathrm{H}, \mathrm{CH}_{2}$ ), 4.17 (br. s, $\left.1 \mathrm{H}, \mathrm{CH}\right), 4.68-4.91$ (m, $2 \mathrm{H}, \mathrm{CH}$ and $\mathrm{NH}$ ), 6.226.37 (dd, $1 \mathrm{H}, J=7.8 \mathrm{~Hz}, \mathrm{NH}), 6.92-7.03$ (m, $4 \mathrm{H}, \mathrm{HAr}$ ), 7.47-7.51 (dd, $1 \mathrm{H}$ $J=2.4$ and $5.4 \mathrm{~Hz}, \mathrm{HAr}), 7.83-7.92(\mathrm{~m}, 5 \mathrm{H}, \mathrm{HAr}), 7.97-8.14(\mathrm{~m}, 4 \mathrm{H}$, HAr) ppm. ${ }^{13} \mathrm{C}$ NMR (75.5 MHz, $\left.\mathrm{CDCl}_{3}\right) \delta: 28.15$ and $28.20\left(\mathrm{CH}_{3}\right), 35.64$ and $35.79\left(\mathrm{CH}_{2}\right), 38.36\left(\mathrm{CH}_{2}\right), 52.31$ and $52.34\left(\mathrm{OCH}_{3}\right), 53.73$ and 53.82 $(\mathrm{CH}), 55.75(\mathrm{CH}), 80.22\left[\mathrm{C}\left(\mathrm{CH}_{3}\right)_{3}\right], 122.83$ and $123.02(\mathrm{CH}), 124.75(\mathrm{CH})$, $124.84(\mathrm{C}), 125.08(\mathrm{C}), 125.15(\mathrm{CH}), 125.30(\mathrm{CH}), 126.04(\mathrm{CH}), 126.92$ $(\mathrm{CH}), 127.31(\mathrm{CH}), 127.44(\mathrm{CH}), 127.91(\mathrm{CH}), 127.44$ and $128.04(\mathrm{CH})$, $128.60(\mathrm{CH}), 129.27$ and $129.32(\mathrm{CH}), 129.41$ and $129.52(\mathrm{C}), 129.70$ and $129.79(\mathrm{C}), 130.69$ and $130.73(\mathrm{C}), 130.76$ and $130.79(\mathrm{C}), 131.36(\mathrm{C})$, $136.48(\mathrm{C}), 155.28(\mathrm{C}=\mathrm{O}), 155.25(\mathrm{C}=\mathrm{O}), 170.90$ and $171.04(\mathrm{C}=\mathrm{O})$, 171.59 and $171.89(\mathrm{C}=\mathrm{O})$ ppm. HMRS (ESI): calcd. for $\mathrm{C}_{34} \mathrm{H}_{34} \mathrm{~N}_{2} \mathrm{NaO}_{5}$ 573.23654; found 573.2374 .

Synthesis methyl 2-[2-(tert-butoxycarbonylamino)propanamido]-3(naphthalen-1-yl)propanoate 7:

The general procedure described above was followed with compound methyl 2-[2-(tert-butoxycarbonylamino)propanamido]acrylate $(0.2 \mathrm{mmol}$, $54.5 \mathrm{mg})$ and 1-naphthaleneboronic acid $(0.8 \mathrm{mmol}, 138 \mathrm{mg})$ to give compound $7(57.3 \mathrm{mg}, 72 \%)$ as an oil. ${ }^{1} \mathrm{H}$ NMR $\left(300 \mathrm{MHz}, \mathrm{CDCl}_{3}\right) \delta$ : 1.15-1.21 (m, $\left.3 \mathrm{H}, \mathrm{CH}_{3}\right), 1.35\left(\mathrm{~s}, 9 \mathrm{H}, \mathrm{CH}_{3}\right), 3.46-3.54\left(\mathrm{~m}, 5 \mathrm{H}, \mathrm{CH}_{2}\right.$ and $\mathrm{OCH}_{3}$ ), 4.05 (q, $\left.1 \mathrm{H}, J=7.2 \mathrm{~Hz}, \mathrm{CH}\right), 4.73$ (br. s, $\left.1 \mathrm{H}, \mathrm{NH}\right), 4.85-4.94$ (m, 1 $\mathrm{H}, \mathrm{CH}), 6.54-6.65$ (dd, $1 \mathrm{H}, J=6.9 \mathrm{~Hz}, \mathrm{NH}), 7.16-7.19$ (m, $1 \mathrm{H}, \mathrm{HAr}), 7.31$ (t, $1 \mathrm{H}, J=8.1 \mathrm{~Hz}, \mathrm{HAr}$ ), 7.38-751 (m, $2 \mathrm{H}, \mathrm{HAr}), 7.70$ (d, $1 \mathrm{H}, J=8.1 \mathrm{~Hz}$, HAr), 7.78 (d, $1 \mathrm{H}, J=8.4 \mathrm{~Hz}, \mathrm{HAr}$ ), 8.00-8.05 (dd, $1 \mathrm{H}, J=3.0$ and $5.4 \mathrm{~Hz}$ HAr) ppm. ${ }^{13} \mathrm{C}$ NMR (75.5 MHz, $\left.\mathrm{CDCl}_{3}\right) \delta: 18.17\left(\mathrm{CH}_{3}\right), 28.28$ and 28.30 $\left(\mathrm{CH}_{3}\right), 35.31$ and $35.46\left(\mathrm{CH}_{2}\right), 52.31\left(\mathrm{OCH}_{3}\right), 53.08$ and $53.20(\mathrm{CH}), 60.44$ $(\mathrm{CH}), 80.24\left[\mathrm{C}\left(\mathrm{CH}_{3}\right)_{3}\right], 123.43$ and $123.58(\mathrm{CH}), 125.26$ and $125.29(\mathrm{CH})$, $125.82(\mathrm{CH}), 126.36$ and $126.44(\mathrm{CH}), 127.49(\mathrm{CH}), 128.02$ and 128.05 $(\mathrm{CH}), 128.90(\mathrm{CH}), 132.05$ and $132.16(\mathrm{C}), 132.20$ and $132.26(\mathrm{C}), 13387$ (C), $155.45(\mathrm{C}=\mathrm{O}), 171.98$ and $172.14(\mathrm{C}=\mathrm{O}), 172.26$ and $171.32(\mathrm{C}=\mathrm{O})$ ppm. HMRS (ESI): calcd. for $\mathrm{C}_{22} \mathrm{H}_{29} \mathrm{~N}_{2} \mathrm{O}_{5} 401.20765$; found 401.2097.

Synthesis methyl 2-[2-bis(tert-butoxycarbonyl)amino- $N$-(tert-

butoxycarbonyl)propanamido]-3-(naphthalen-1-yl)propanoate 8 :

The general procedure described above was followed with compound methyl 2-2-[bis(tert-butoxycarbonyl)amino]- $N$-(tertbutoxycarbonyl)propanamido]acrylate $(0.2 \mathrm{mmol}, 95 \mathrm{mg})$ and 1naphthaleneboronic acid $(0.8 \mathrm{mmol}, 138 \mathrm{mg})$ to give compound $8(20.0 \mathrm{mg}$, $17 \%)$ as an oil. ${ }^{1} \mathrm{H}$ NMR (300 $\left.\mathrm{MHz}, \mathrm{CDCl}_{3}\right) \delta: 1.40-1.44\left(\mathrm{~m}, 30 \mathrm{H}, \mathrm{CH}_{3}\right)$, 3.29-3.37 (dd, $1 \mathrm{H}, J=5.7$ and $\left.8.7 \mathrm{~Hz}, \mathrm{CH}_{2}\right), 3.57\left(\mathrm{~s}, 3 \mathrm{H}, \mathrm{OCH}_{3}\right), 3.66(\mathrm{t}, 1$ $\mathrm{H}, J=10.2 \mathrm{~Hz}, \mathrm{CH}), 3.92-3.99\left(\mathrm{dd}, 1 \mathrm{H}, J=7.5\right.$ and $\left.6.9 \mathrm{~Hz}, \mathrm{CH}_{2}\right), 5.48-$ $5.56(\mathrm{~m}, 1 \mathrm{H}, \mathrm{CH}), 7.29-7.51(\mathrm{~m}, 4 \mathrm{H}, \mathrm{HAr}), 7.66$ (d, $1 \mathrm{H}, J=8.1 \mathrm{~Hz}, \mathrm{HAr})$, $7.77(\mathrm{~d}, 1 \mathrm{H}, J=6.9 \mathrm{~Hz}, \mathrm{HAr}), 8.11(\mathrm{~d}, 1 \mathrm{H}, J=8.1 \mathrm{~Hz}, \mathrm{HAr}) \mathrm{ppm} .{ }^{13} \mathrm{C}$ NMR (75.5 MHz, $\left.\mathrm{CDCl}_{3}\right) \delta$ : $15.85\left(\mathrm{CH}_{3}\right), 27.65$ and $28.04\left(\mathrm{CH}_{3}\right), 33.55$ $\left(\mathrm{CH}_{2}\right), 52.19\left(\mathrm{OCH}_{3}\right), 56.98(\mathrm{CH}), 57.66(\mathrm{CH}), 82.60$ and $83.85\left[\mathrm{C}\left(\mathrm{CH}_{3}\right)_{3}\right]$, $124.00(\mathrm{CH}), 125.13$ and $125.32(\mathrm{CH}), 125.52(\mathrm{CH}), 125.90(\mathrm{CH}), 126.16$ $(\mathrm{CH}), 127.40$ and $127.62(\mathrm{CH}), 128.49$ and $128.72(\mathrm{CH}), 132.03(\mathrm{C})$, $133.81(\mathrm{C}), 134.37(\mathrm{C}), 151.67$ and $152.59(\mathrm{C}=\mathrm{O}), 170.85(\mathrm{C}=\mathrm{O}), 173.52$
(C=O) ppm. HMRS (ESI): calcd. for $\mathrm{C}_{32} \mathrm{H}_{44} \mathrm{~N}_{2} \mathrm{NaO}_{9}$ 623.29445; found 623.2946 .

Supporting Information (see footnote on the first page of this article): ... ((Copies of the ${ }^{1} \mathrm{H}$ NMR and ${ }^{13} \mathrm{C}$ NMR spectra are REQUIRED for all key intermediates and final products; additional information as needed.))

\section{Acknowledgments}

Thanks are due to the Foundation for Science and Technology (FCT, Portugal), QREN and FEDER/EU for financial support through the research centers, CQ/UM [PEst-C/QUI/UI0686/2011 (FCOMP-01-0124FEDER-022716)]) and CFUM [PEst-C/FIS/UI0607/2011 (F-COMP-010124-FEDER-022711)], and project PTDC/QUI/81238/2006 (cofinanced by FEDER/COMPETE, ref. FCOMP-01-0124-FEDER-007467). G. Pereira (SFRH/BD/38766/2007) acknowledges her PhD grant to FCT, POPHQREN, FSE.

[1] a) K. Yoshida, T. Hayashi in Modern Rhodium-Catalysed Organic reactions (Eds.: P. A. Evans) Wiley-VCH:Weinheim, Germany, 2005, Chapter 3; b) H. J. Edwards, J. D. Hargrave, S. D. Penrose, C. G. Frost, Chem. Soc. Rev. 2010, 39, 2093-2105; c) J. C. Allen, G. Kociok-Köhn, C. G. Frost, Org. Biomol.Chem. 2012, 10, 32-35.

[2] a) C. J. Chapman, C. G. Frost, Adv. Synth. Catal. 2003, 345, 353355; b) C. J. Chapman, K. J. Wadsworth, C. G. Frost J. Organometallic Chem. 2003, 680, 206-211; c) C. J. Chapman, J. D. Hargrave, G. Bish, C. G. Frost Tetrahedron 2008, 64, 9528-9539; d) J. D. Hargrave, G. Bish, G.K. Kociok-Köhn, C.G. Frost, Org. Biomol. Chem. 2010, 8, 5120-5125; e) D. Ray, A. M. Nyong, A. Natarajan, Tetrahedron Lett. 2010, 51, 2655-2656.

[3] a) P. M. T. Ferreira, H. L. S. Maia, L. S. Monteiro, J. Sacramento J Chem. Soc., Perkin Trans. 1 1999, 3697-3703; b) P. M. T. Ferreira H. L. S. Maia, L. S. Monteiro, J. Sacramento J. Chem. Soc., Perkin Trans. 1 2001, 3167-3174; c) P. M. T. Ferreira, H. L. S. Maia, L. S. Monteiro Eur. J. Org. Chem. 2003, 2635-2644; d) A. S. Abreu, P. M. T. Ferreira, L. S. Monteiro, M-J. R. P. Queiroz, I. C. F. R. Ferreira, R. C. Calhelha, L. M. Estevinho, Tetrahedron 2004, 60, 11821-11828; e) P. M. T. Ferreira, L. S. Monteiro, G. Pereira, L. Ribeiro, J Sacramento, L. Silva Eur. J. Org. Chem. 2007, 5934-5949.

[4] I. B. Berlman, Handbook of Fluorescence Spectra of Aromatic Molecules, Academic Press, London, 1971.

[5] Y. Nakamura, T. Tsuihiji, T. Mita, T. Minowa, S. Tobita, H Shizuka, J. Nishimura, J. Am. Chem. Soc. 1996, 118, 1006-1012.

[6] N .J. Turro, J. C. Scaiano, V. Ramamurthy, in Modern Molecular Photochemistry of Organic Molecules, University Science Books, Sausalito (California), 2009.

[7] W. H. Melhuish, J. Phys. Chem. 1961, 65, 229-235; b) W. R Dawson, M. W. Windsor, J. Phys. Chem. 1968, 72, 3251-3260.

[8] P. M. T. Ferreira, L. S. Monteiro, E. M. S. Castanheira, G. Pereira C. Lopes, H. Vilaça, Tetrahedron 2011, 67, 193-200.

[9] B. Valeur, Molecular Fluorescence: Principles and Applications, Wiley-VCH, Weinheim, 2001.

[10] D. C. Dong, M. A. Winnik, Can. J. Chem. 1984, 62, 2560-2565.

[11] J. R. Lakowicz, Principles of Fluorescence Spectroscopy, 2nd Ed., Kluwer Academic/Plenum Publishers, New York, 1999.

[12] M. R. Eftink, Intrinsic fluorescence of proteins in: Topics in fluorescence spectroscopy (Ed.: J. R. Lakowicz), Kluwer Academic/Plenum Publishers, New York, 2000, pp. 1-13.

[13] G. A. Crosby, J. N. Demas, J. Phys. Chem. 1971, 75, 991-1024.

[14] S. Fery-Forgues, D. Lavabre, J. Chem. Educ. 1999, 76, 1260-1264.

Received: ((will be filled in by the editorial staff)) Published online: ((will be filled in by the editorial staff)) 
Several fluorescent $\beta$-arylalanine derivatives were prepared in good yields using a rhodium catalysed conjugate addition of arylboronic acids to $\mathrm{N}$-protected dehydroalanines. The photophysical properties of some of the $\beta$-arylalanines were studied in three solvents of different polarity and considering the relatively high fluorescence quantum yield of these compounds, some of them may be useful as fluorescent markers.

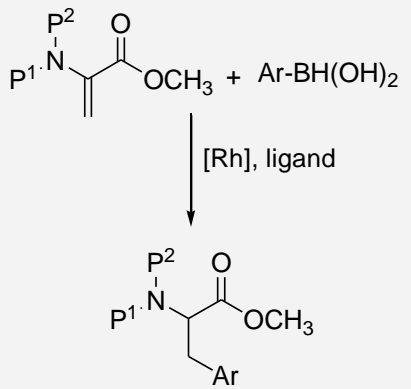

P.M.T. Ferreira, ${ }^{*}$ L.S. Monteiro, G. Pereira, E.M.S. Castanheira and C.G. Frost*........Page No. - Page No.

Synthesis of fluorescent alanines by a rhodium catalysed conjugate addition of arylboronic acids to dehydroalanine derivatives

Keywords: dehydroalanines / rhodiumcatalysis / arylboronic acids / conjugate addition / fluorescent marker 
Supporting Information

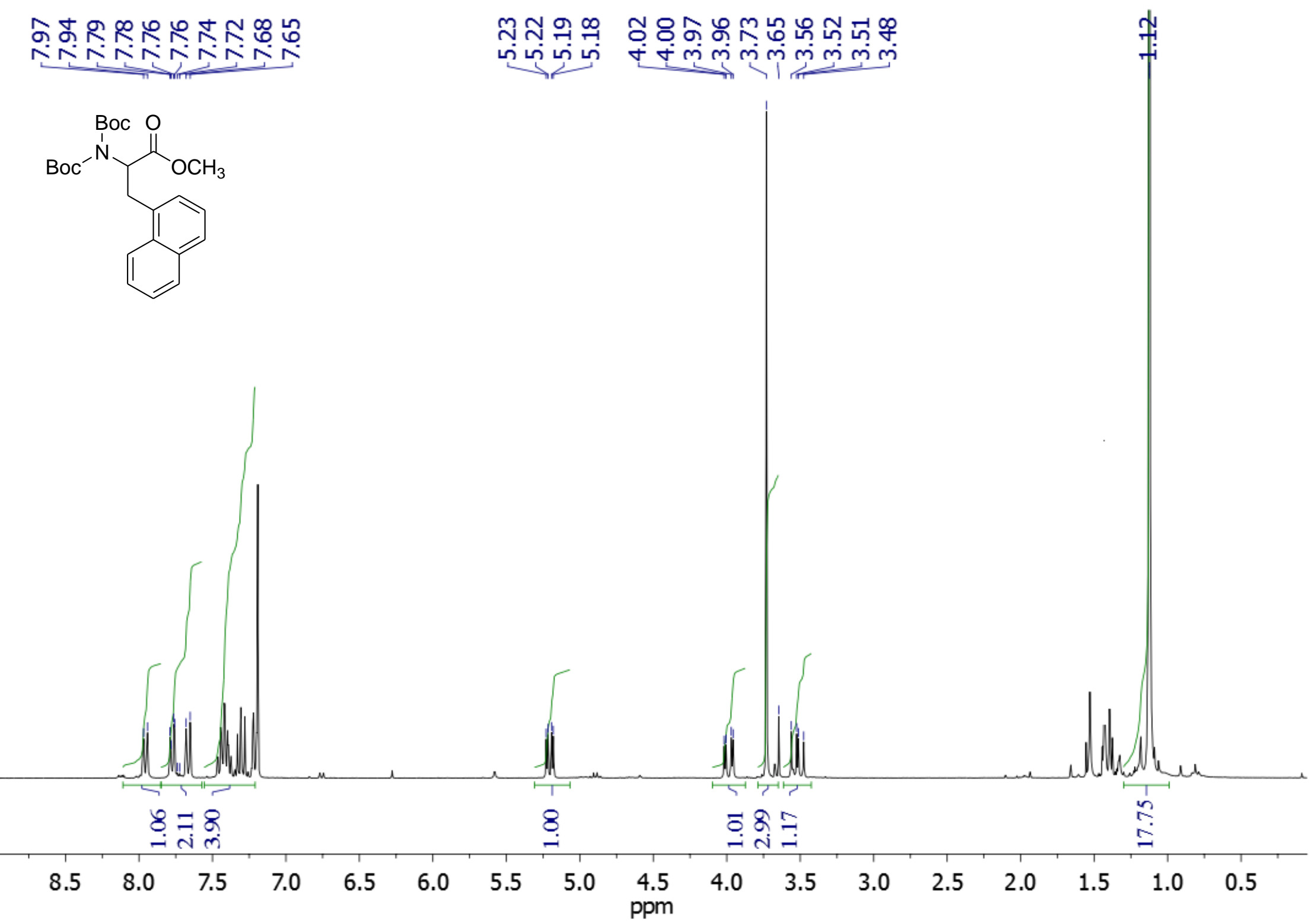



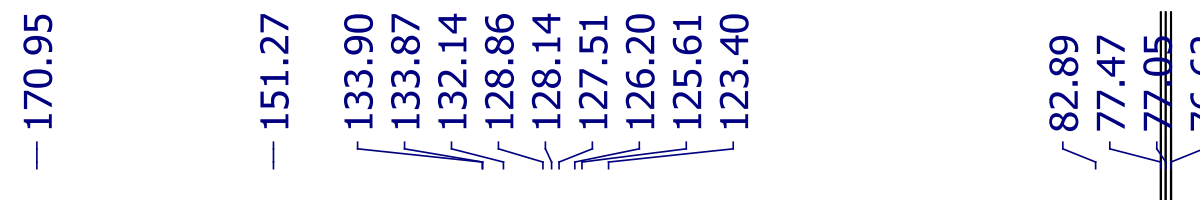

$\begin{array}{cc}\text { 우 } & \text { ั } \\ \text { กิ่ } & \text { กี่ } \\ \text { | }\end{array}$

ㄴํㅇำ

m

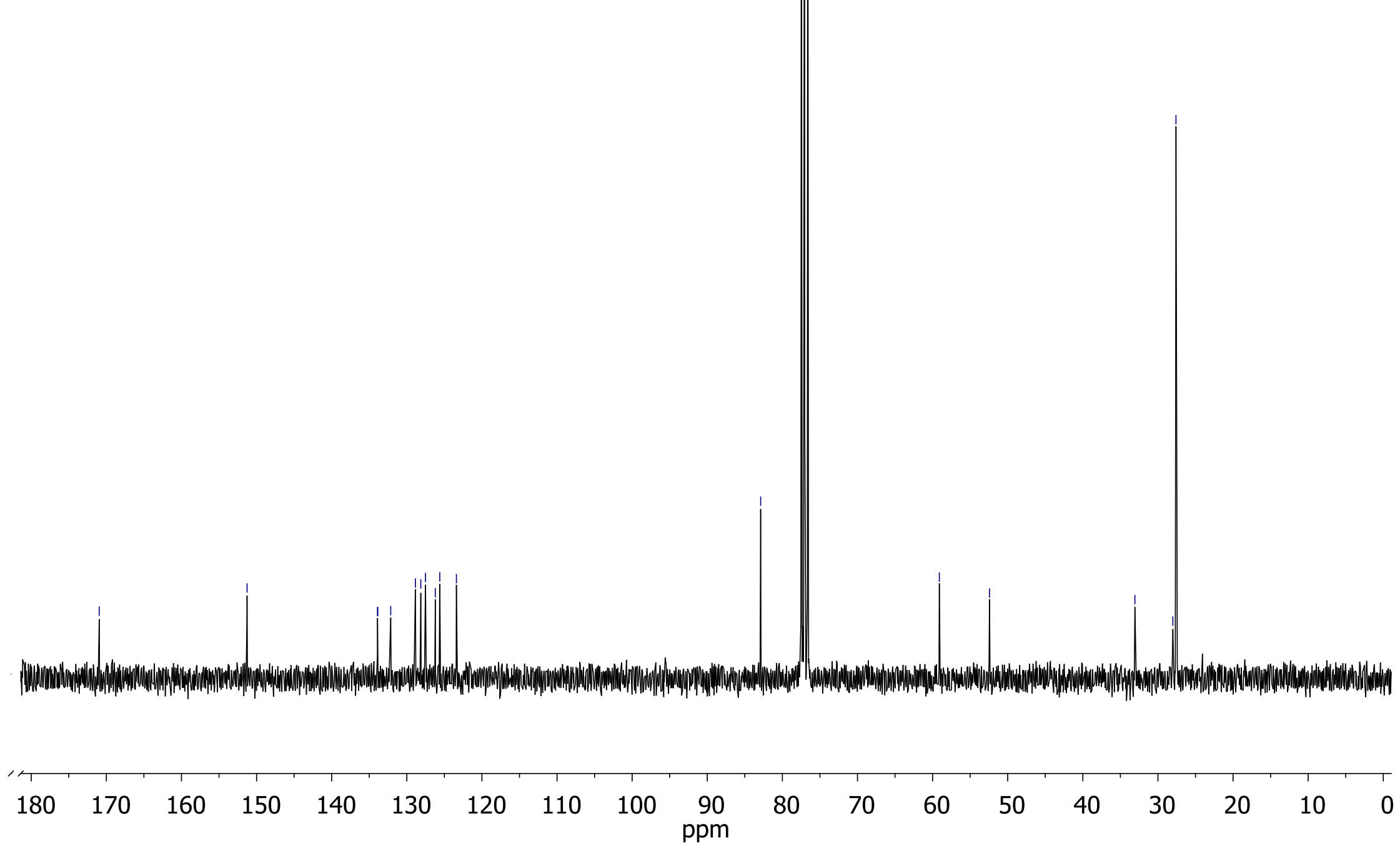




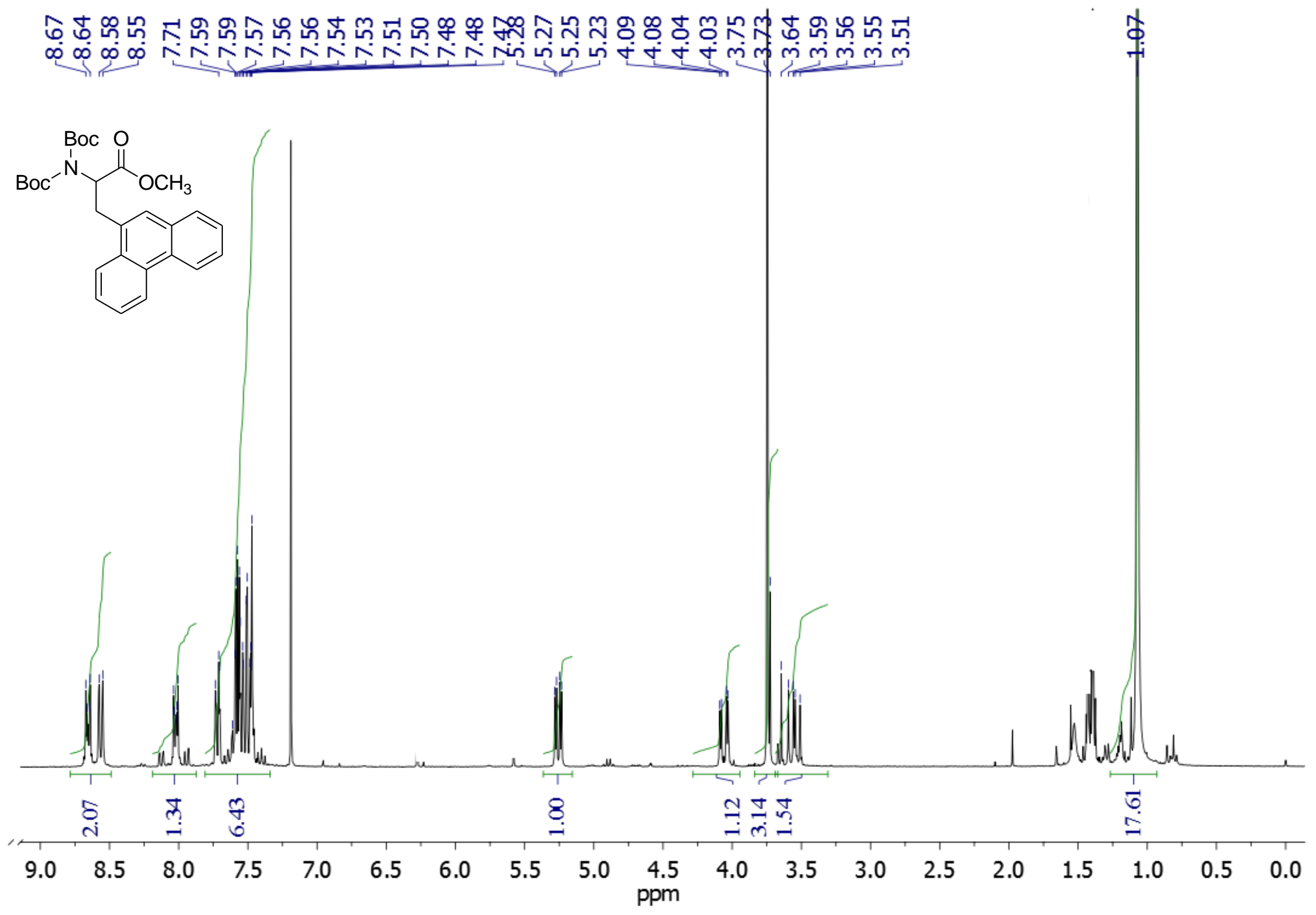




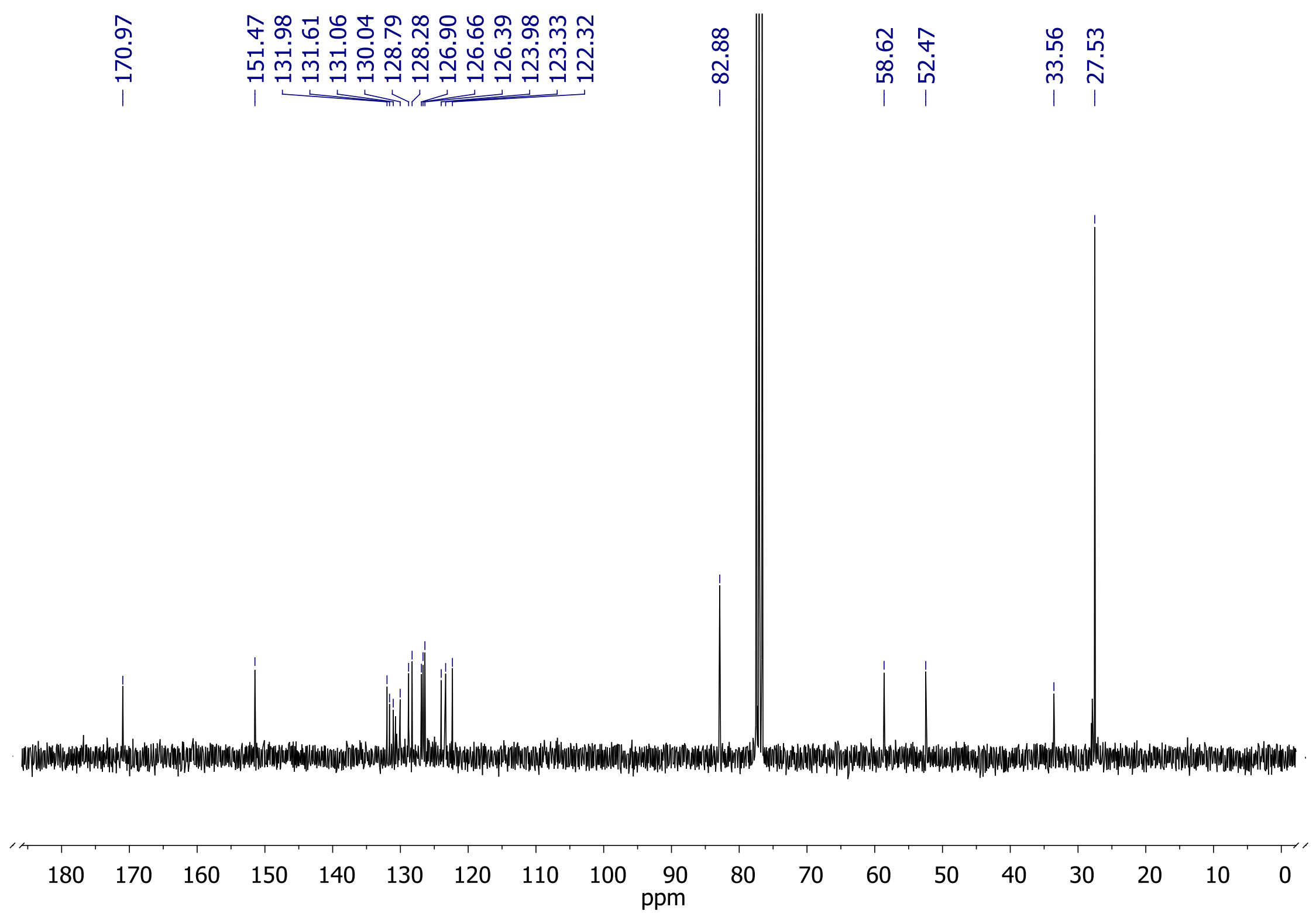




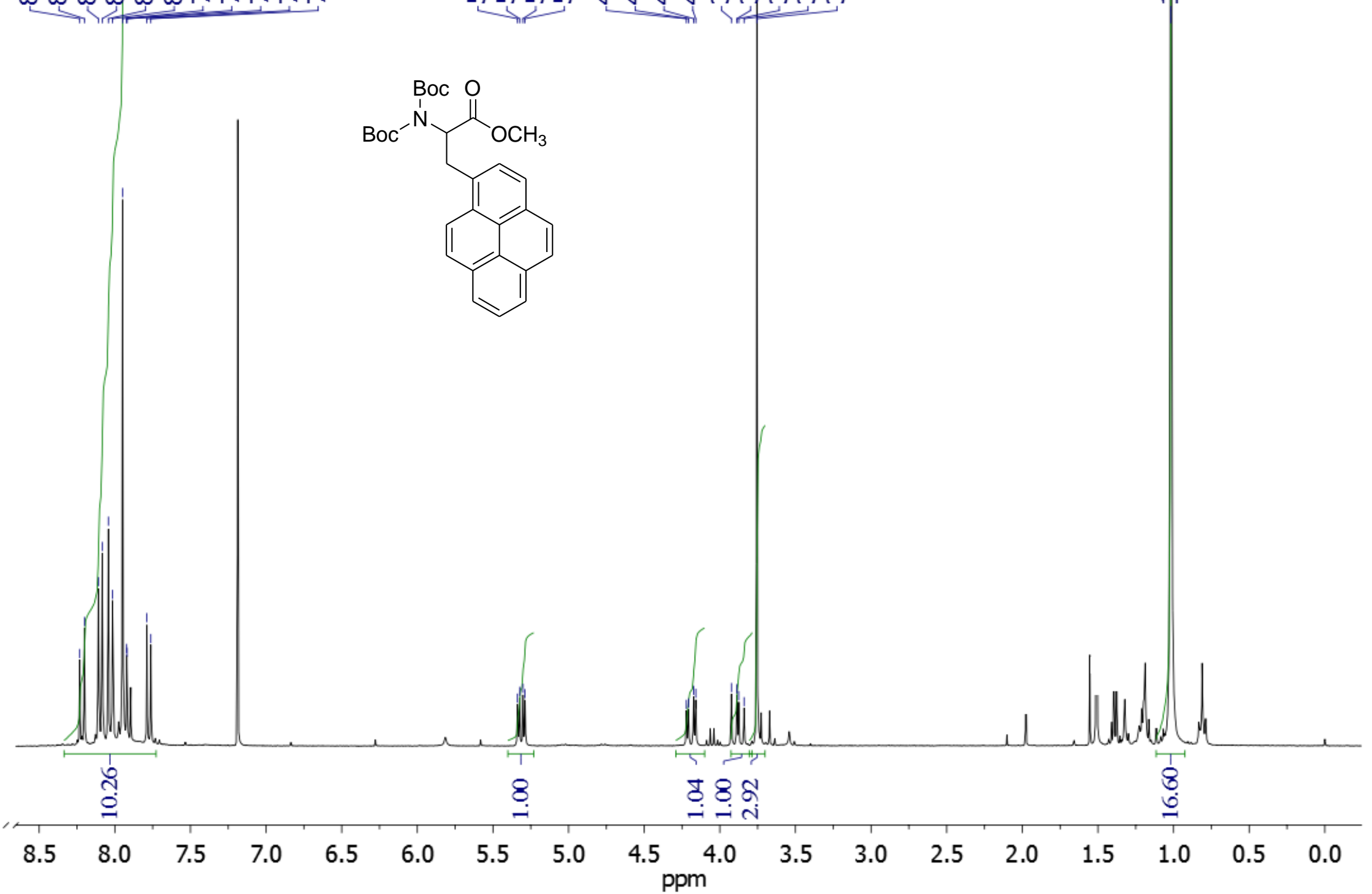




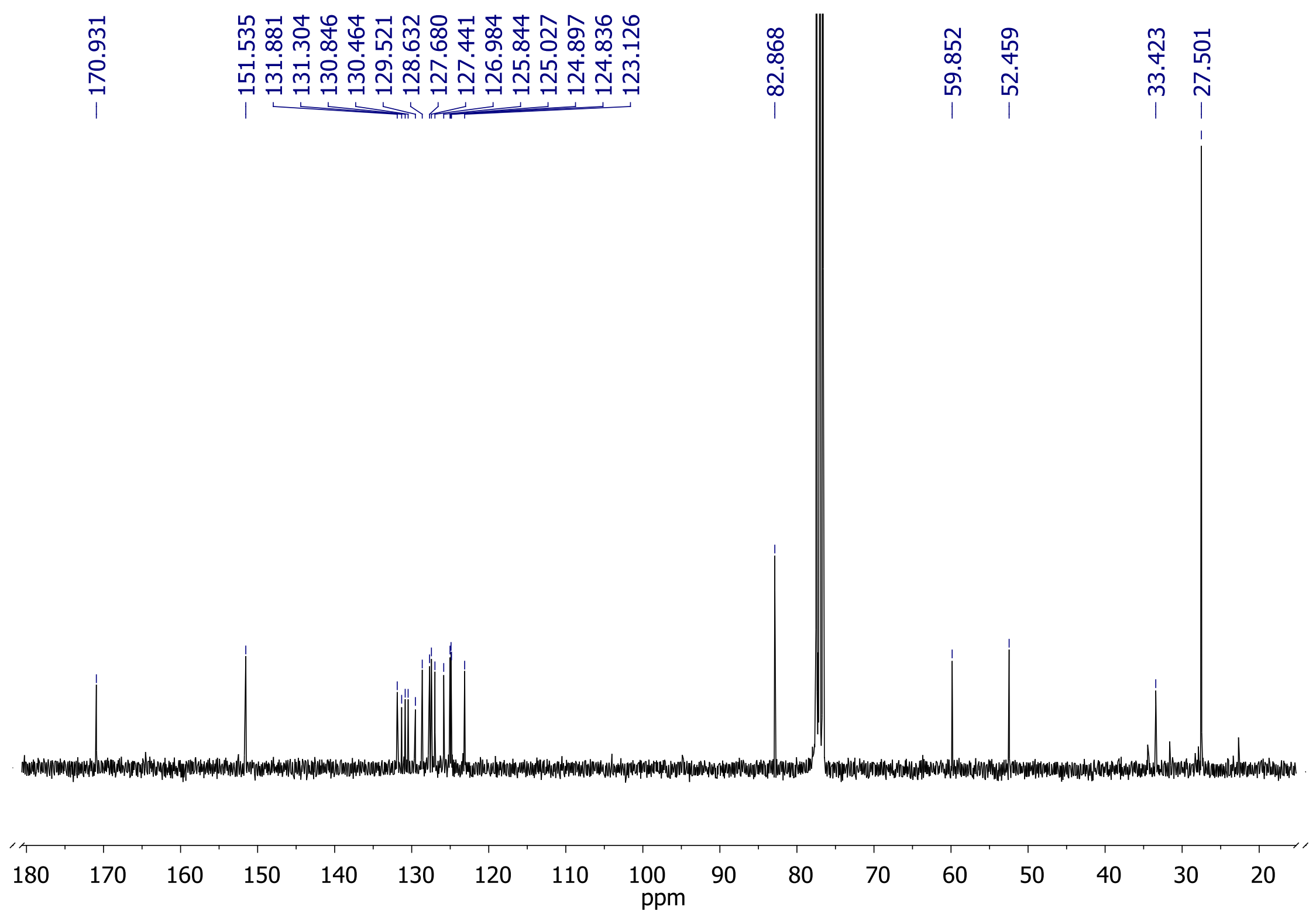




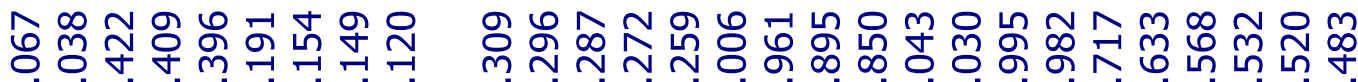

$\infty \infty^{\circ} \wedge$ N $N$ N

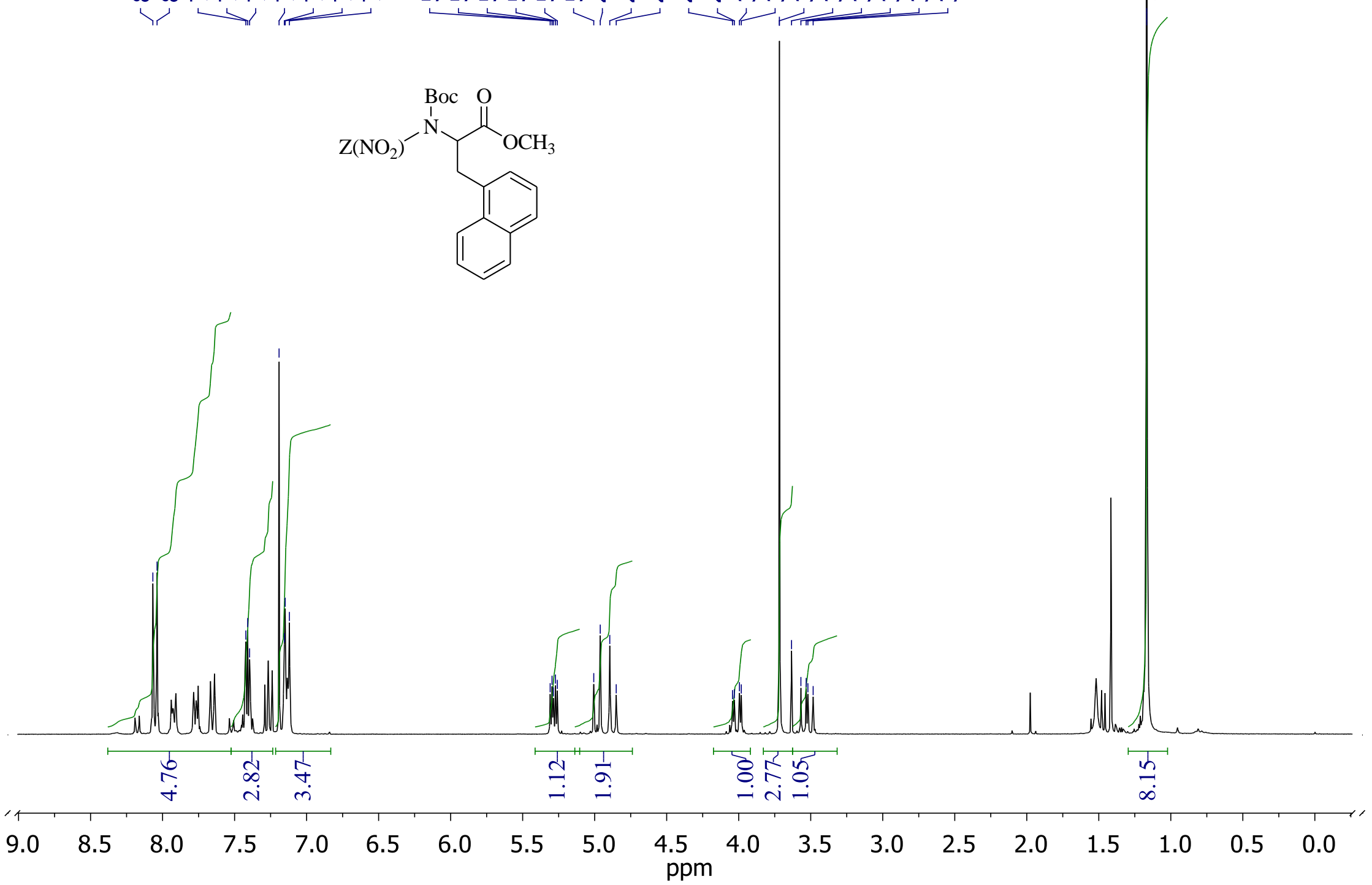




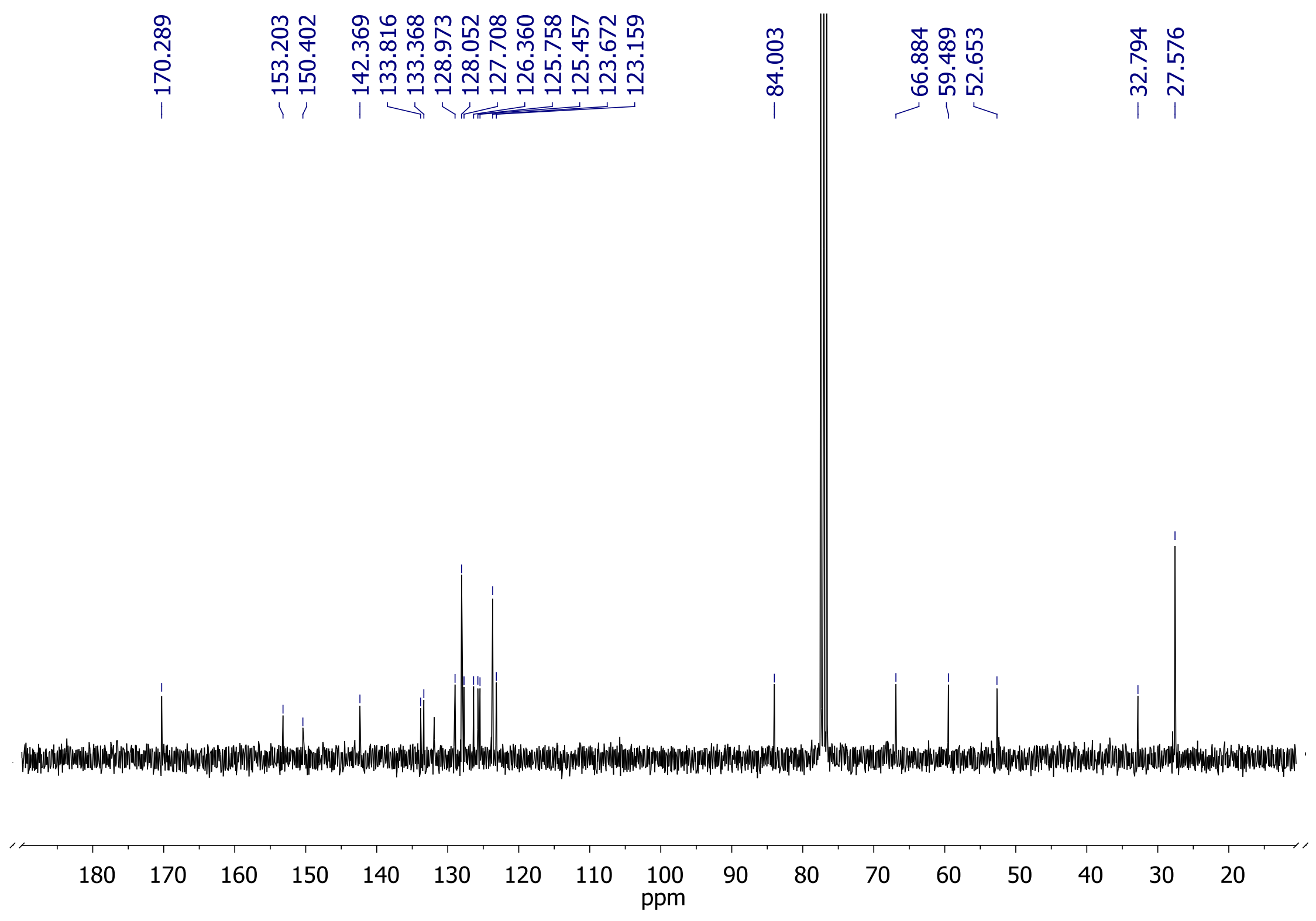




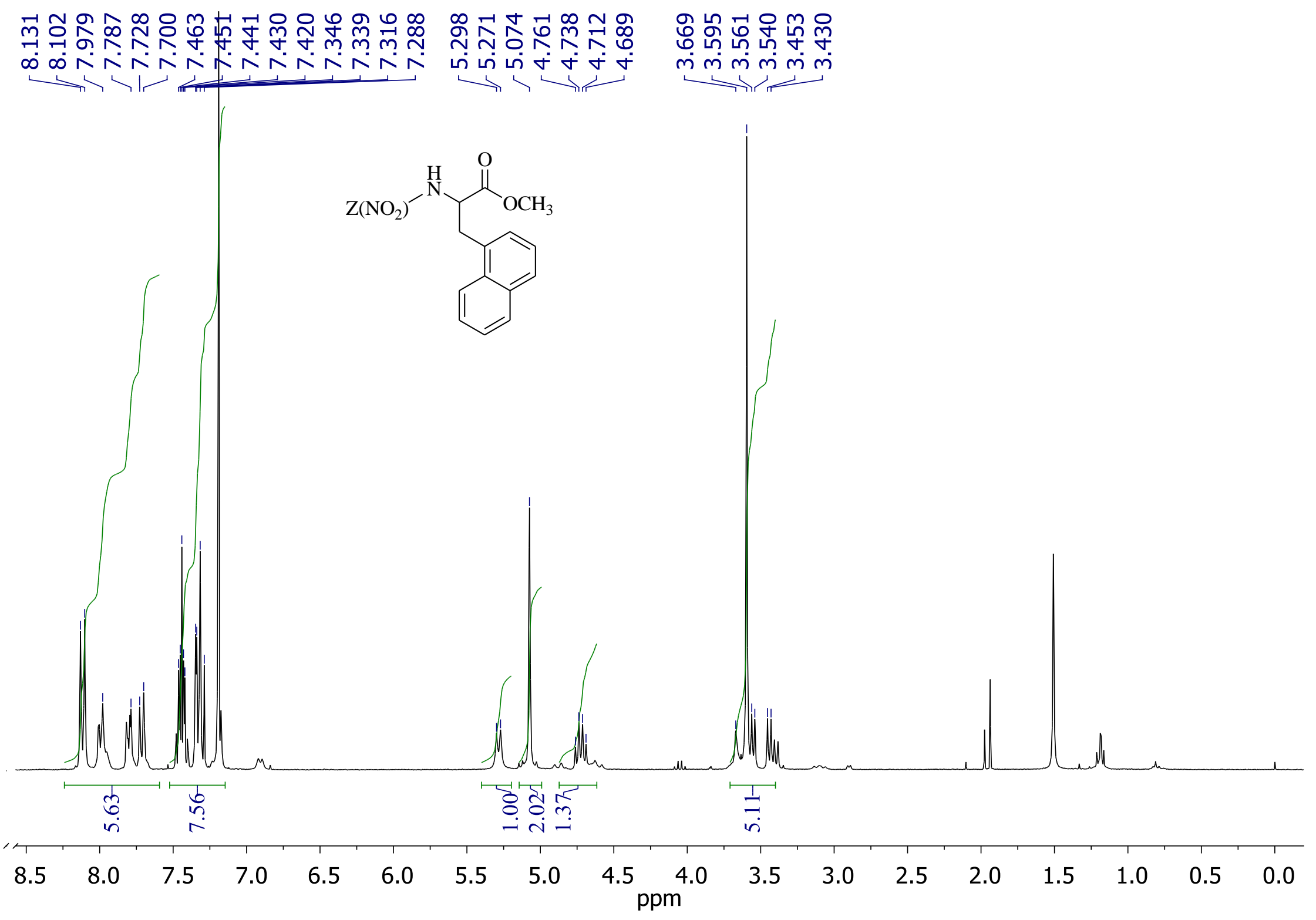




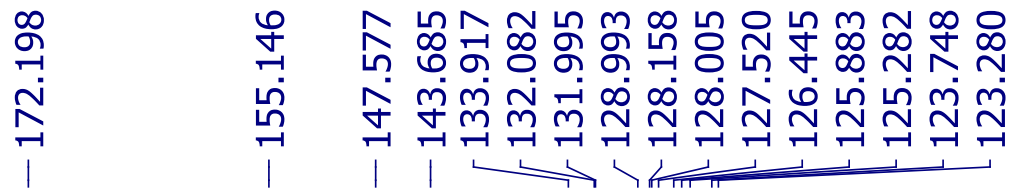

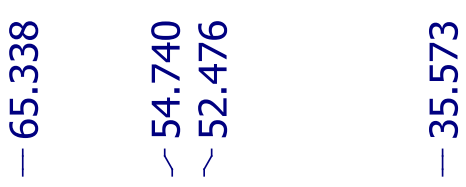

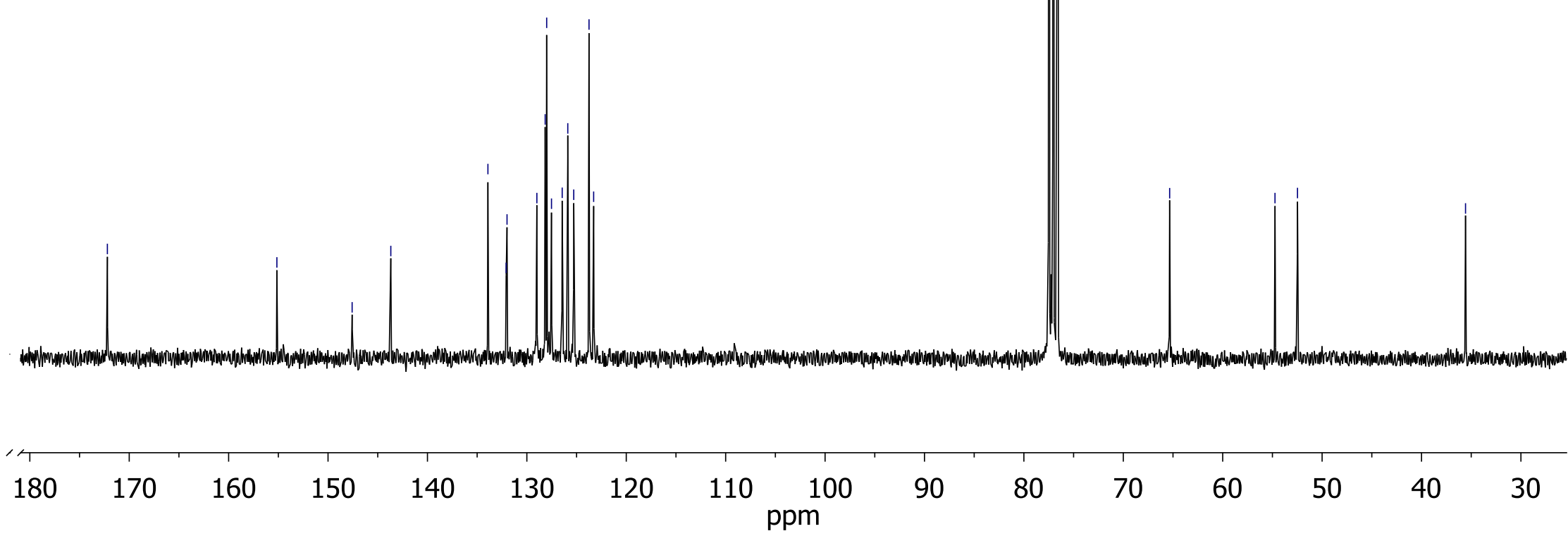




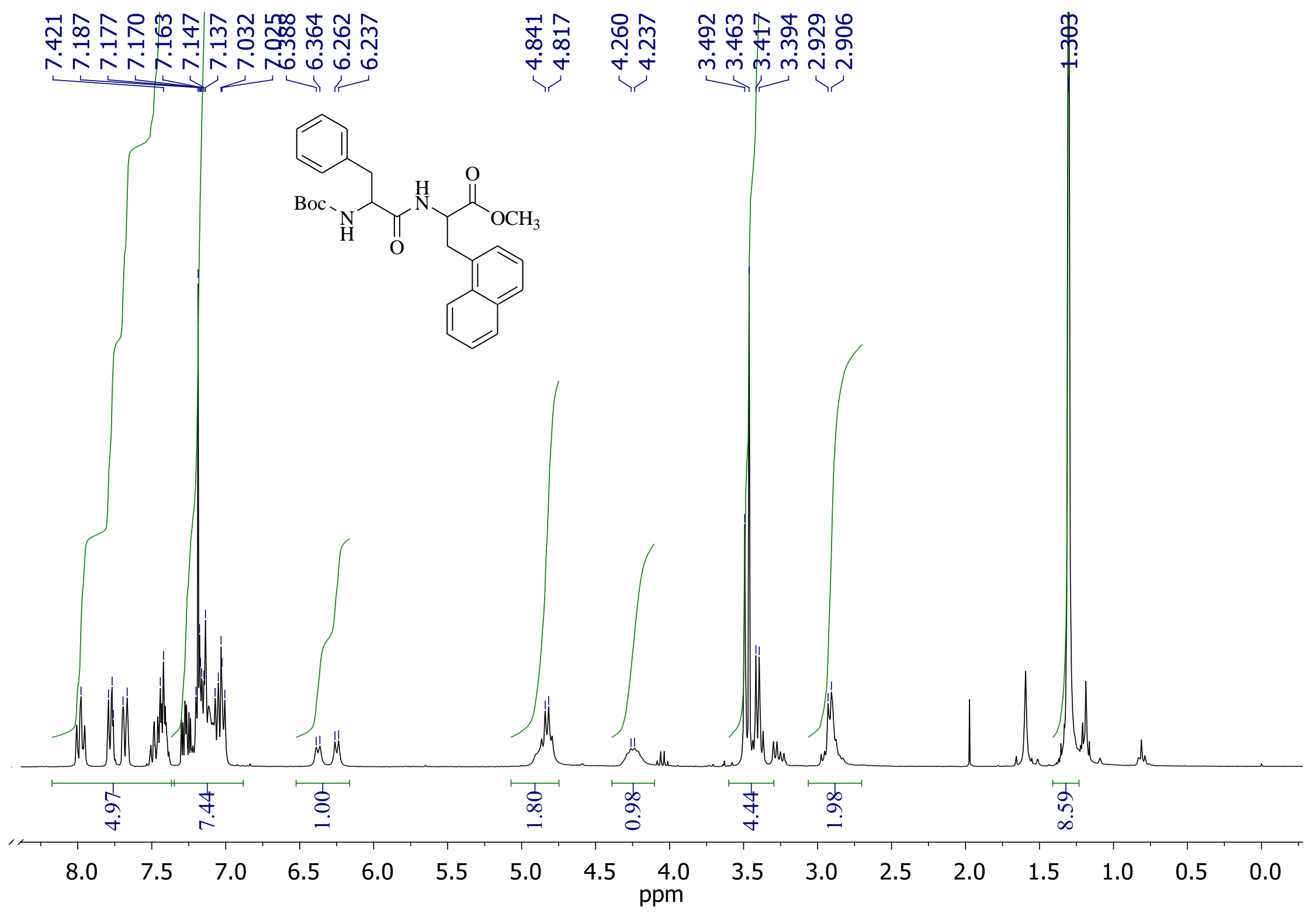




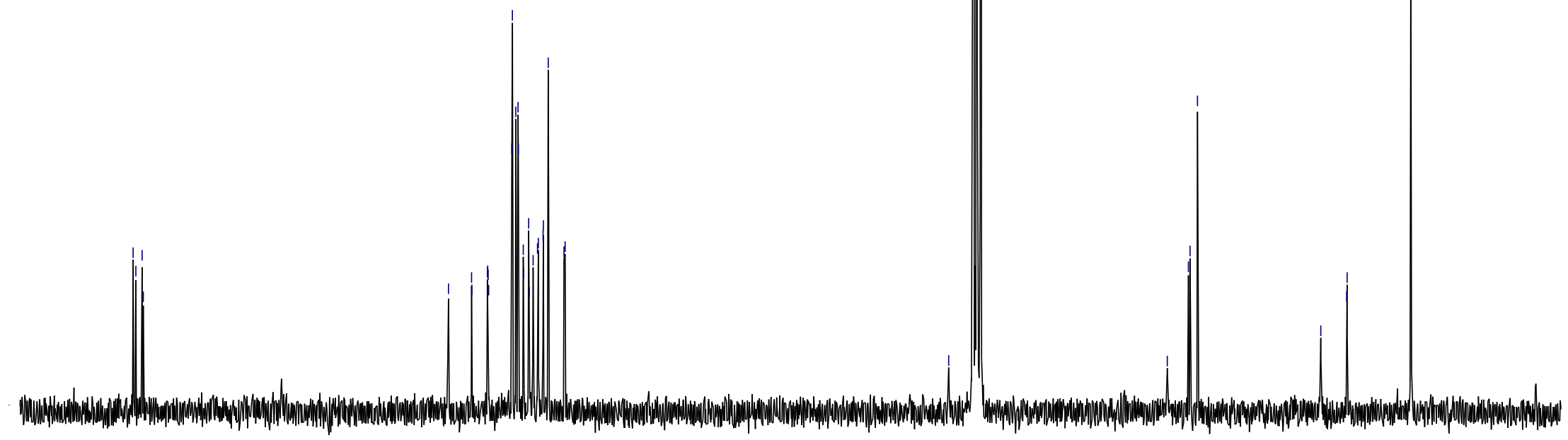

\begin{tabular}{|c|c|c|c|c|c|c|c|c|c|c|c|c|c|c|c|c|}
\hline 180 & 170 & 160 & 150 & 140 & 130 & 120 & 110 & $\begin{array}{c}100 \\
\mathrm{ppm}\end{array}$ & 90 & 80 & 70 & 60 & 50 & 40 & 30 & 20 \\
\hline
\end{tabular}




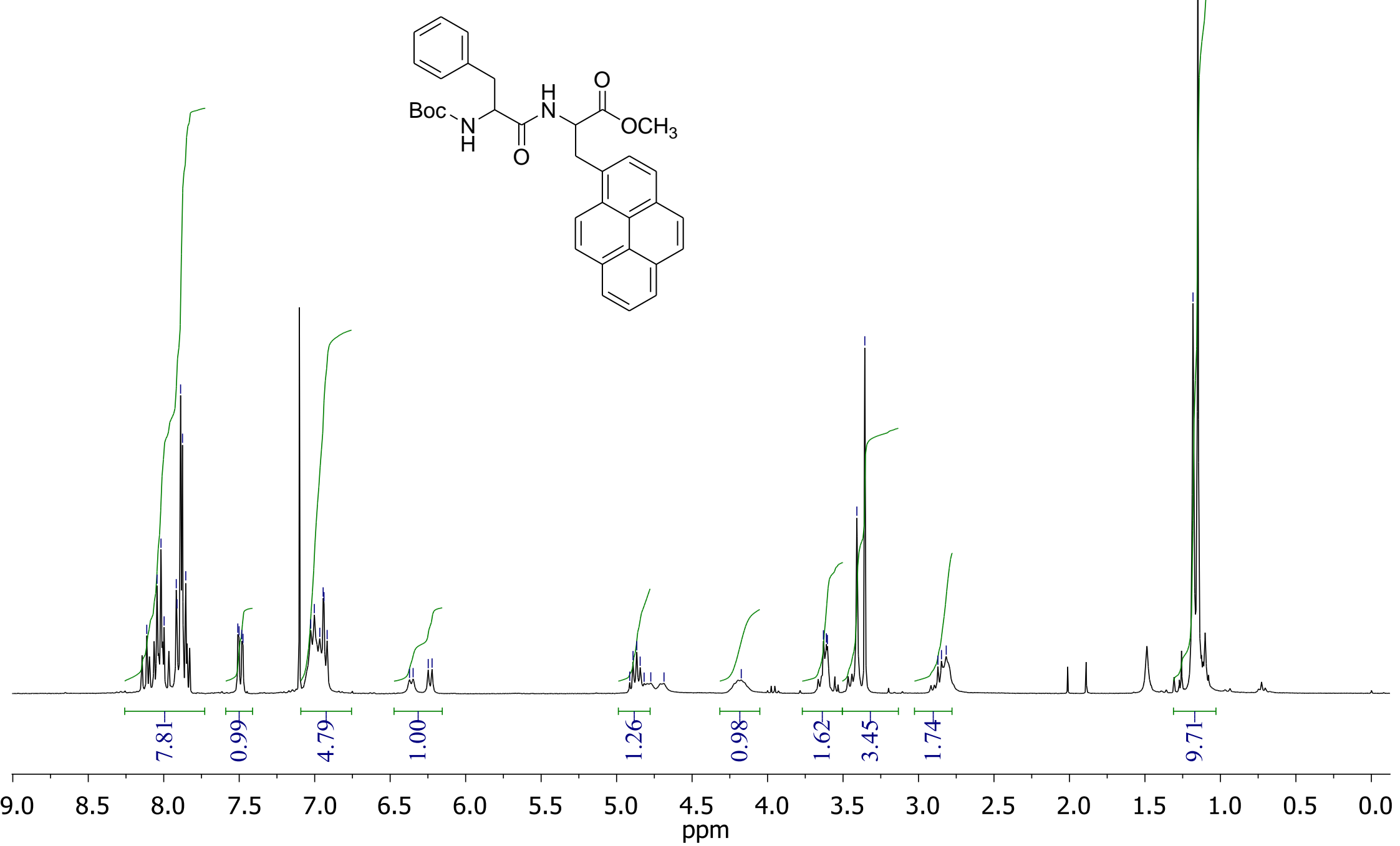



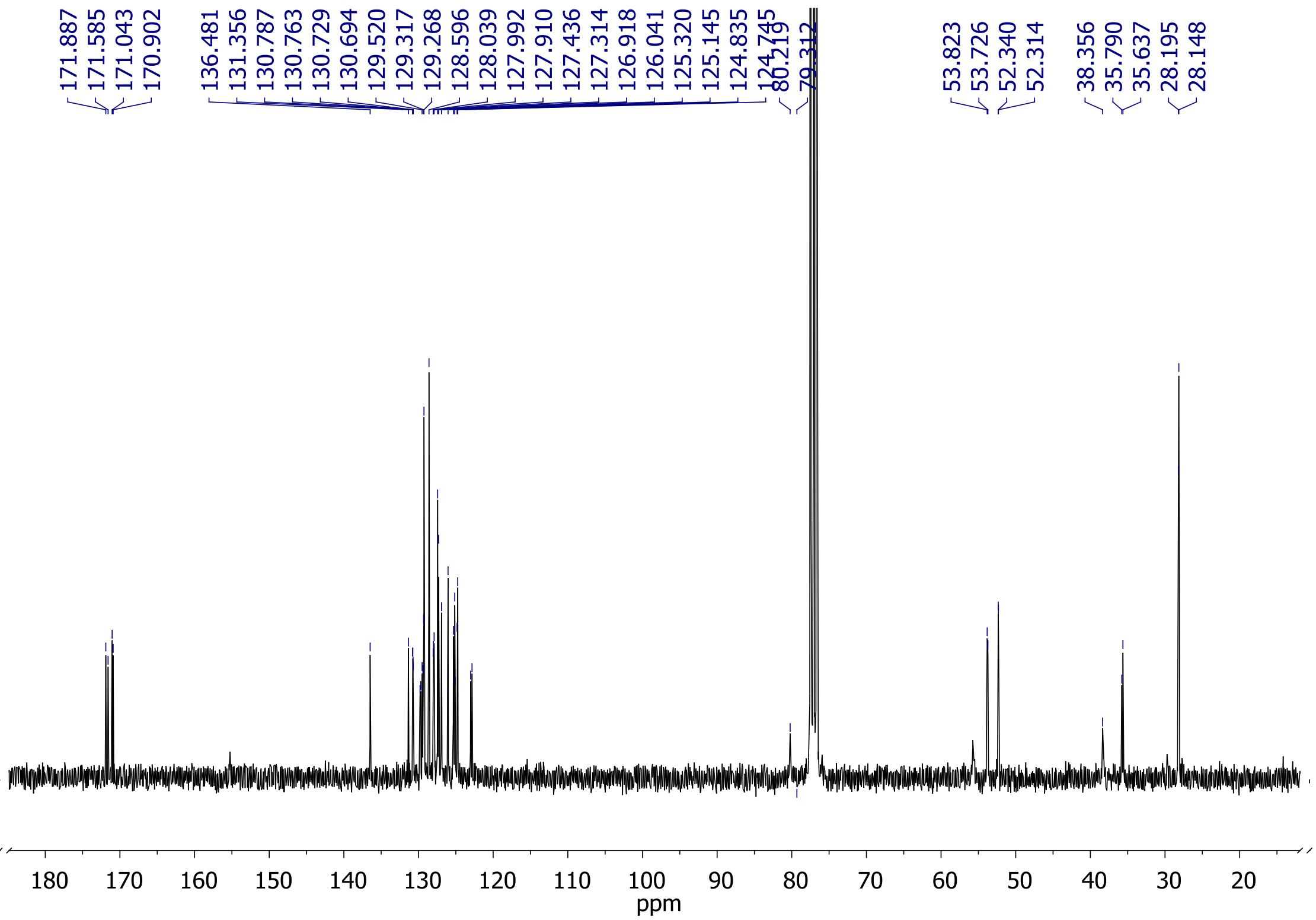


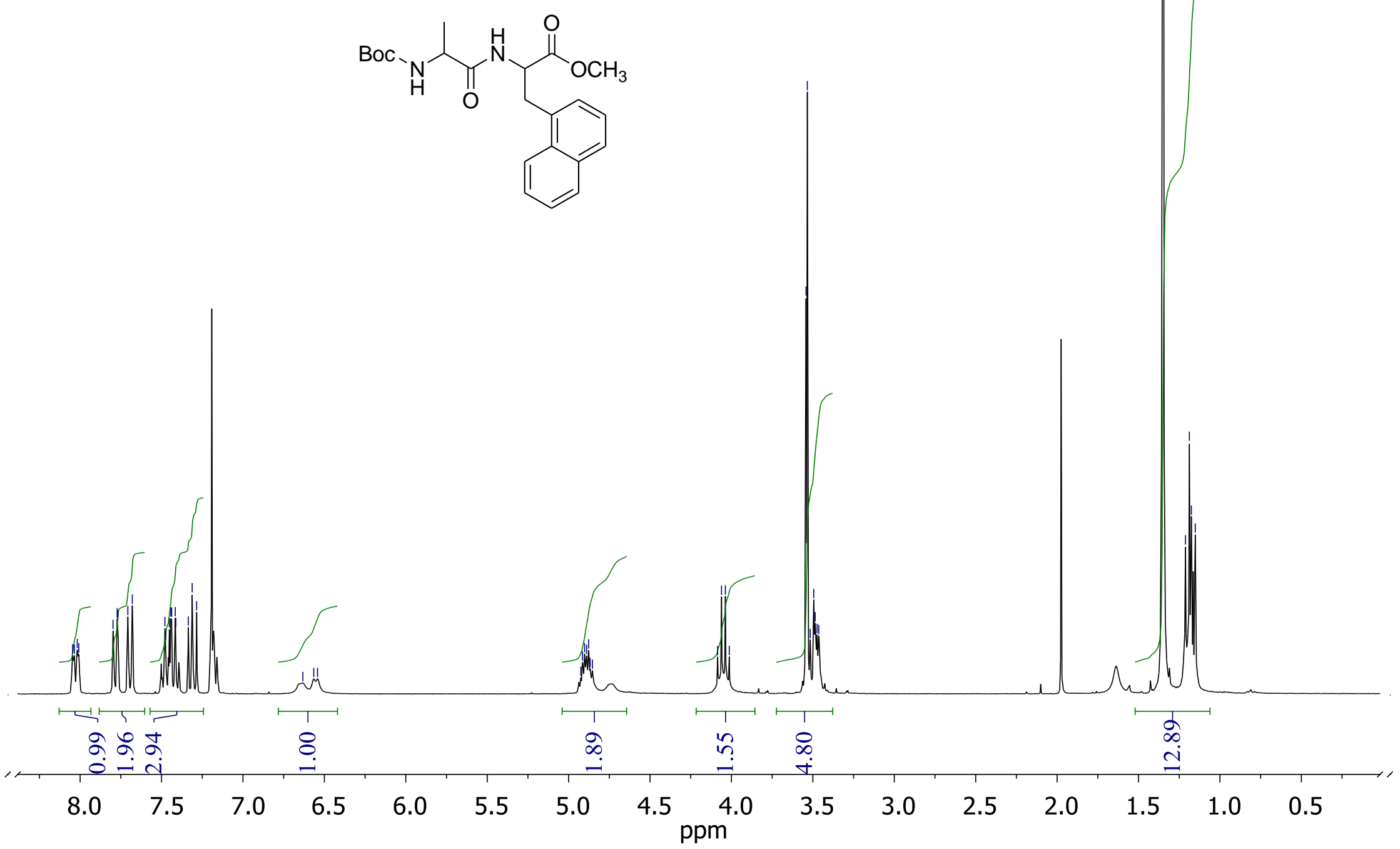




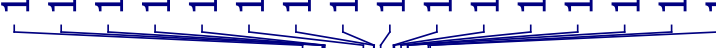
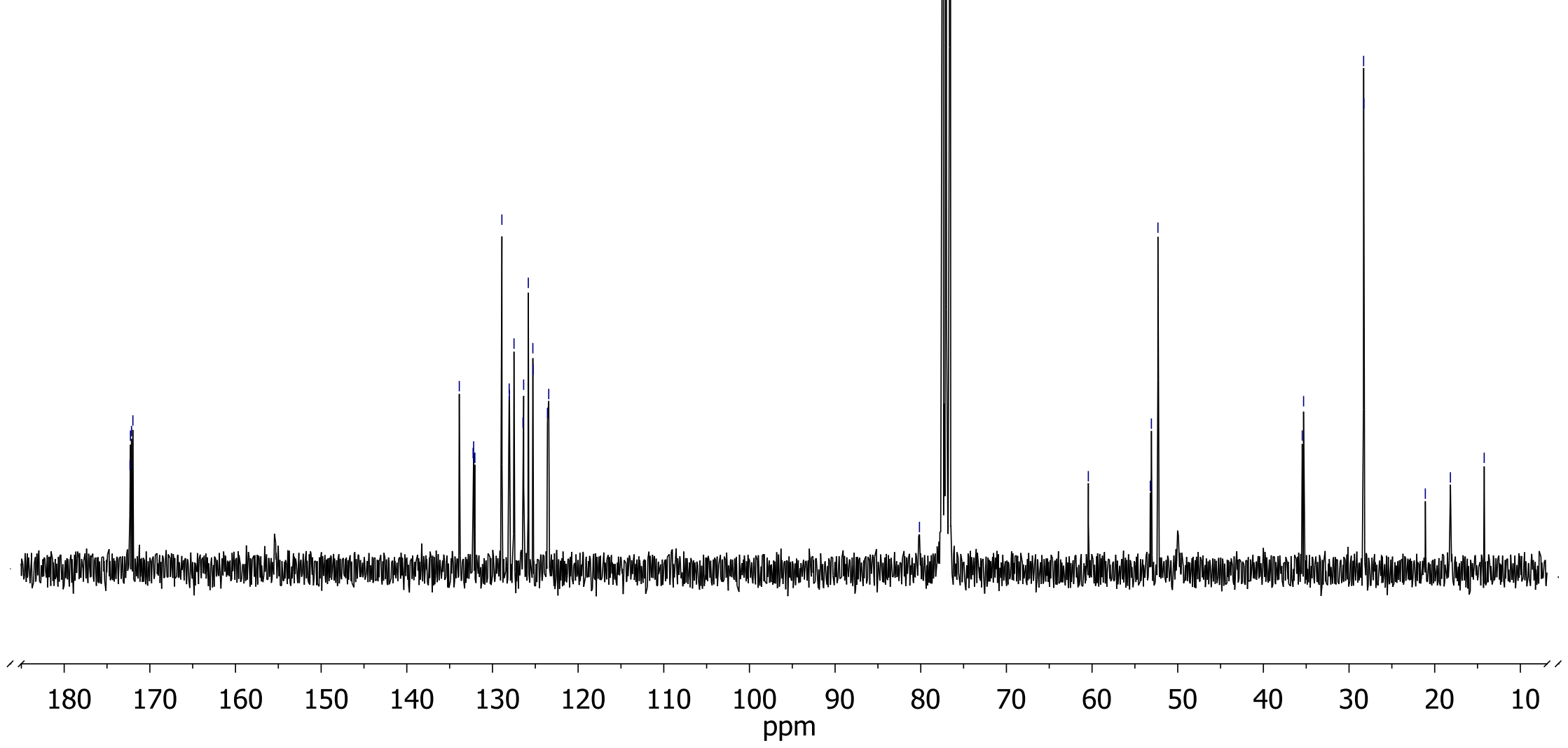


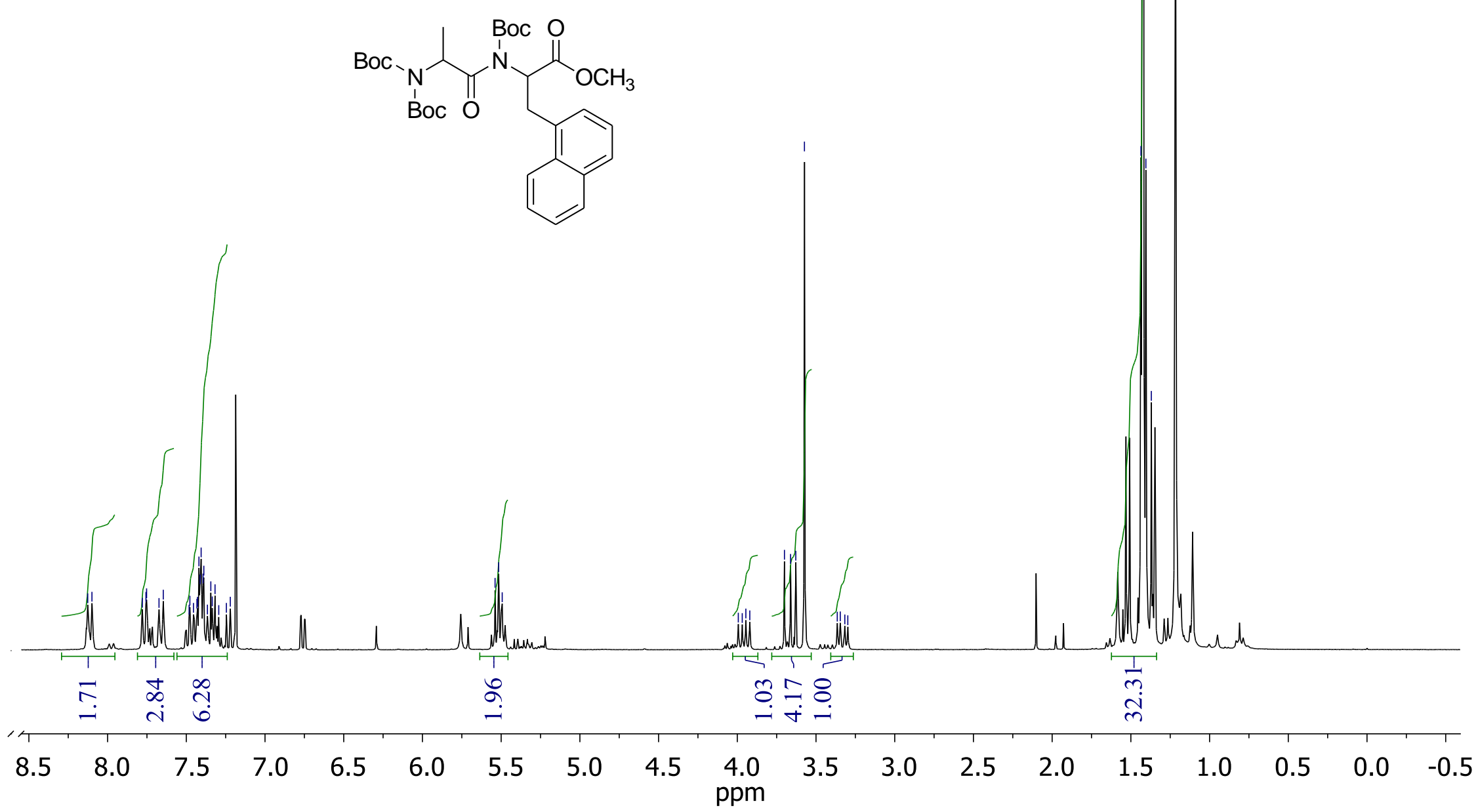



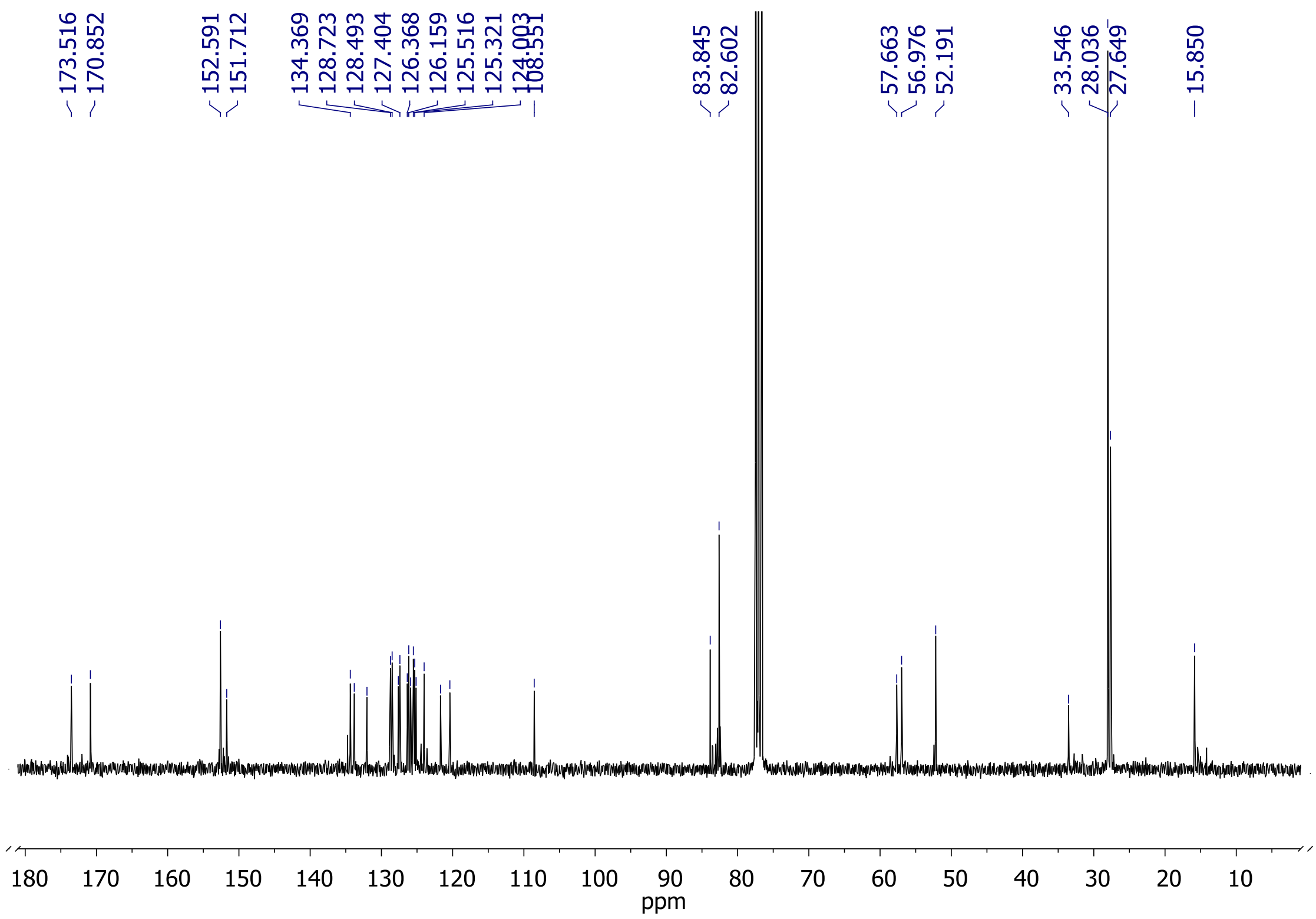